\title{
Comparative Study of Form and Features of Courtyards in Terms of Outdoor Thermal Comfort in Two Contrasting Climates of Iran
}

\author{
Morteza Ojaghlou ${ }^{1} \&$ Mehdi Khakzand ${ }^{2}$ \\ ${ }^{1}$ MS of Department of Architecture, Qazvin Branch, Islamic Azad University, Qazvin, Iran \\ ${ }^{2}$ Assistant professor in landscape architecture, School of Architecture and Environmental Design, Iran University \\ of Science and Technology, Tehran, Iran \\ Correspondence: Mehdi KhakZand, Assistant professor in landscape architecture, School of Architecture and \\ environmental design, Iran University of Science and Technology, Tehran, Iran. Tel: 98-21-7724-0467. E-mail: \\ mkhakzand@iust.ac.ir
}

Received: January 15, 2018

doi:10.5539/jsd.v11n2p112
Accepted: February 28, $2018 \quad$ Online Published: March 30, 2018

URL: https://doi.org/10.5539/jsd.v11n2p112

\begin{abstract}
Courtyards as a traditional strategy were used to create a suitable microclimate for dwellers, but in contemporary architecture, inadequate knowledge of form and features of courtyards makes them deficient. This study presents practical solutions reaching optimal form and features of courtyards based on the traditional architecture of two contrasting climates of Iran. The ENVI-met.4 model was used for simulating the area percentage, water and vegetation level in a very cold climate of Ardabil and Hot-arid climate of Yazd. The simulated atmospheric parameters were imported to the Rayman 1.2 to calculate PET thermal index. As the first step, $10 \%$ of the total area was advised to be considered a courtyard area for Yazd hot-arid climate, and $60 \%$ of the total area was recommended in a very cold climate of Ardabil. Next, the ratio of the water area to the total area of courtyards was simulated and the results advice, $0 \%$ of the courtyard to be considered a water area of Ardabil and $10 \%$ of the courtyard of Yazd is an optimum choice in hot-arid climate. In the final step, $20 \%$ of courtyards recommended the best condition of tree coverage in both climates. By these guidelines, designers can create a more adaptive architecture to the local climate.
\end{abstract}

Keywords: outdoor thermal comfort, courtyards, microclimate, contrasting climates, ENVI-met4

\section{Introduction}

Open spaces usually cover more than two-thirds of the urban area in modern architecture; thus their microclimate dominates the urban canopy layer (UCL) climate. (Shashua-Bar \& Hoffman, 2004).

Perfecting the thermal environment of buildings and their surrounding outdoor environment is a multidisciplinary necessity to create an urban microclimate and achieving outdoor thermal comfort (Berkovic et al., 2012; Wong et al., 2003; Saito et al., 1990; Wong et al., 2011).

Currently, in city development, the Urban Heat Island phenomenon is increasing and the effects of UHI on human health, energy consumption and air quality are considered by researchers. However, architectural tools and forms can play a part in mitigating the effects of UHI, and also in the climatic effect on human comfort levels. (Taleghani et al., 2015; Ali-Toudert et al., 2006; Ahmed, 2003; Johansson, 2006).

Developing an understanding of suitable forms and materials can radically help to adopt thermal environment in outdoor settings, and thus reduce energy consumption in indoor conditions. The courtyard concept is a common and ancient method in architectural design, especially in Middle Eastern countries like Iran. (Edwards, 2006). The advantages of the courtyard and its thermal characteristics have been evaluated by some studies in different climates, both in measurement and computer modeling methods. (Safarzadeh et al., 2005; Taleghani et al., 2014; Aldawoud \& Clark, 2008; Zhai \& Previtali, 2010; Yao \& Steemers, 2013).

There are some studies of courtyard thermal features in the tropical climate (Makaremi et al., 2012; Fahmy \& Sharples, 2009; Rajapaksha et al., 2003; Sadafi et al., 2011) but Iran's courtyards feature in a wide range of different climates, so they warrant detailed investigation. Analogous application of courtyard form, material, and vegetation might cause a malfunction in the performance of courtyards in different climates of Iran. This study aims to evaluate quantitatively the comfort condition of the courtyards in two different climates of Iran in terms 
of dimension, vegetation, and water level. This study is being carried out in order to develop guidelines for creating more sustainable environments in these climates.

\section{Material and Methods}

\subsection{Simulation Software and Thermal Index}

The thermal performance features of the courtyards were analyzed based on the following design parameters: the dimension, vegetation, and water. These parameters are selected based on the real examples of the courtyard features in Iran. These 3 parameters are the most important issues in courtyard planning. It should be noted that there is enough research about other parameters (like albedo of the materials and the height and wall enclosure), and the results of the simulation are predictable. For example; materials with high albedo make outdoor conditions, more and more exposed to high radiation, and also SVF has an effect on the comfort condition. The result of these studies proved that shaded places have a better condition in terms of thermal comfort (Taleghani et al., 2015; Makaremi et al., 2012; Ghaffarianhoseini et al., 2015).

So analyzing and simulating the local and practical parameters for local courtyards is a fundamental issue. ENVI-met 4, a three-dimensional fluid dynamics microclimate software, was used to simulate the outdoor thermal condition of the courtyards. With Version 4.0 the microclimate simulation ENVI-met takes a huge step forward in terms of the accuracy and realism of the simulations. Due to the new $3 \mathrm{D}$ format, there are no longer any limits to the architecturally detailed reproduction of the model area.

The new features of the ENVI-met 4 are mentioned according to the following items:

3: Forcing (Huttner, \&Bruse, 2009).

(i) Full 3D editor

(ii) Advanced calculation of façade temperature and wall energy balance.

(iii) Forcing (Huttner, \&Bruse, 2009).

One of the most important features of ENVi-met software is its capability to generate the accurate Tmrt for the outdoor condition (Huttner et al., 2008; Chow \&Brazel, 2012) and to calculate the Physiological Equivalent Temperature (PET).

Table 1. PET thermal comfort category (Hoppe, 1999)

\begin{tabular}{ccc}
\hline PET $^{\circ} \mathrm{C}$ & Thermal Perception & A grade of physiological stress \\
\hline Below +4 & Very cold & Extreme cold stress \\
4 to 8 & Cold & Strong cold stress \\
8 to 13 & Cool & Moderate cold stress \\
13 to 18 & Slightly cool & Slight cold stress \\
18 to 23 & Comfortable & No thermal stress \\
23 to 29 & Slightly warm & Slight heat stress \\
29 to 35 & Warm & Moderate heat stress \\
34 to 41 & Hot & Strong heat stress \\
$41<$ & Very hot & Extreme heat stress \\
\hline
\end{tabular}

\subsection{Study Area}

A simulation method was employed for analyzing the thermal effect of courtyards in Ardabil and Yazd, Iran. These two cities in Iran have completely different climates. Ardabil $\left(48^{\circ} 18^{\prime} \mathrm{E}\right.$. Long, $38^{\circ} 15^{\prime} \mathrm{N}$. lat) is located in the northwest of Iran and it has a very cold climate. Because of its rash, cold climate, designing the outdoor spaces in this city has some limits and specific principles. There is an impact of the cold wind and solar radiation, humidity, etc. (Jalilian \& Tahbaz, 2006; Namin \& Khoshvalad, 2015). Yazd $\left(55^{\circ} 0^{\prime} \mathrm{E}\right.$. long, $32^{\circ} 0^{\prime} \mathrm{N}$. lat) is situated in the center of Iran. This city has a hot and arid climate. Outdoor spaces in this region need special attention to possible ventilation and solar radiation (Hedari, 2010; Teimourtash, 2013). A very cold and long winter is one of the most significant features of the Ardabil climate. In table 1, the long-term climatic data of Ardabil are presented for the 1976 to 2010 period, and also the Physiological Equivalent Temperature (PET) is calculated. 
The calculations of PET are done via Rayman for a normal 35-year-old male person of $1.75 \mathrm{~m}$ high and $75 \mathrm{~kg}$, with a metabolic rate of 80 Watt (the Rayman default parameters). An activity level of $80 \mathrm{~W}$ arises when a normal person is walking with $1.2 \mathrm{~m} / \mathrm{s}$. PET frequency is presented in Fig1.

Table 2. Longtime meteorological data of Ardabil (1976-2010) (chaharmahalmet. ir, 2016)

\begin{tabular}{cccccccccc}
\hline & & & $\mathrm{T}_{\mathrm{a}}$ & $\mathrm{RH} \%$ \\
$($ Mean $)$ & (Min) & $\begin{array}{c}\text { RH\% } \\
(\text { Max })\end{array}$ & $\begin{array}{c}\text { RH\% } \\
\text { (Mean) }\end{array}$ & $\begin{array}{c}\text { Wind } \\
\text { Dir }\end{array}$ & $\begin{array}{c}\text { Wind } \\
\text { Speed } \\
\mathrm{m} / \mathrm{s}\end{array}$ & PET \\
\hline JAN & -7.8 & 3.0 & -2.4 & 61 & 87 & 75 & 225 & 18.0 & -9.7 \\
FEB & -5.8 & 4.9 & -0.5 & 58 & 88 & 74 & 225 & 17.5 & -7.2 \\
MAR & -2.0 & 9.8 & 3.9 & 53 & 89 & 73 & 90 & 13.1 & -1.4 \\
APR & 2.9 & 16.6 & 9.7 & 46 & 88 & 68 & 90 & 13.3 & 4.9 \\
MAY & 6.2 & 19.9 & 13.1 & 50 & 91 & 71 & 90 & 13.4 & 8.5 \\
JUNE & 9.2 & 23.4 & 16.3 & 50 & 91 & 71 & 90 & 14.2 & 12.1 \\
JULY & 11.7 & 25.1 & 18.4 & 51 & 88 & 69 & 90 & 15.1 & 14.3 \\
AUG & 11.7 & 25.1 & 18.4 & 51 & 88 & 70 & 90 & 14.5 & 14.5 \\
SEP & 8.9 & 22.7 & 15.8 & 51 & 92 & 74 & 90 & 13.7 & 11.8 \\
OCT & 5.1 & 17.7 & 11.4 & 54 & 92 & 75 & 90 & 13.0 & 7.1 \\
NOV & 0.3 & 11.6 & 5.9 & 55 & 90 & 74 & 225 & 16.5 & 0.3 \\
DEC & -4.5 & 5.9 & 0.7 & 59 & 88 & 74 & 225 & 17.4 & -5.8 \\
\hline
\end{tabular}

The rough cold climate of Ardabil can be understood from table 1, so in this paper; the coldest day of the Ardabil is chosen for the simulation and the calculated data. In contrast, the hot and arid climate of Yazd - with its long-term climatic data - is introduced in table 2. This data is for the period spanning from 1976-2010. The PET value is calculated via Ray man model. Long-term PET frequency of Yazd is presented in Fig2. The differences of the climate data in these cities definitely point to the need for different principles in architecture and urban planning.

Table3. Longtime meteorological data of Yazd (1976-2010) (chaharmahalmet.ir, 2016)

\begin{tabular}{|c|c|c|c|c|c|c|c|c|c|}
\hline & $\mathrm{T}_{\mathrm{a}}(\mathrm{Min})$ & $\mathrm{T}_{\mathrm{a}}(\mathrm{Max})$ & $\begin{array}{c}\mathrm{T}_{\mathrm{a}} \\
\text { (Mean) }\end{array}$ & $\begin{array}{l}\text { RH\% } \\
\text { (Min) }\end{array}$ & $\begin{array}{l}\mathrm{RH} \% \\
\text { (Max) }\end{array}$ & $\begin{array}{c}\text { RH\% } \\
\text { (Mean) }\end{array}$ & $\begin{array}{c}\text { Wind } \\
\text { Dir }\end{array}$ & $\begin{array}{c}\text { Wind } \\
\text { Speed } \\
\mathrm{m} / \mathrm{s}\end{array}$ & PET \\
\hline JAN & -0.4 & 12.3 & 5.9 & 35 & 73 & 54 & 135 & 6.6 & -2.5 \\
\hline FEB & 2.1 & 15.7 & 8.9 & 26 & 65 & 44 & 270 & 8.1 & 1.00 \\
\hline MAR & 6.9 & 20.6 & 13.7 & 21 & 57 & 37 & 270 & 8.8 & 7.1 \\
\hline APR & 12.5 & 26.6 & 19.6 & 19 & 50 & 32 & 270 & 9.2 & 14.5 \\
\hline MAY & 17.6 & 32.3 & 24.9 & 15 & 39 & 25 & 315 & 9.7 & 20.8 \\
\hline JUNE & 22.4 & 37.8 & 30.1 & 12 & 27 & 18 & 315 & 9.0 & 29.2 \\
\hline JULY & 24.5 & 39.5 & 32.0 & 11 & 26 & 17 & 315 & 9.2 & 32.2 \\
\hline AUG & 22.0 & 38.0 & 30.0 & 11 & 26 & 17 & 315 & 8.5 & 28.3 \\
\hline SEP & 17.6 & 34.3 & 25.9 & 12 & 28 & 19 & 315 & 7.9 & 20.9 \\
\hline OCT & 11.5 & 27.7 & 19.6 & 14 & 39 & 27 & 270 & 7.0 & 13 \\
\hline $\mathrm{NOV}$ & 5.1 & 20.0 & 12.5 & 24 & 55 & 38 & 135 & 5.8 & 4.6 \\
\hline DEC & 0.7 & 14.3 & 7.5 & 32 & 68 & 50 & 135 & 6.4 & -0.8 \\
\hline
\end{tabular}




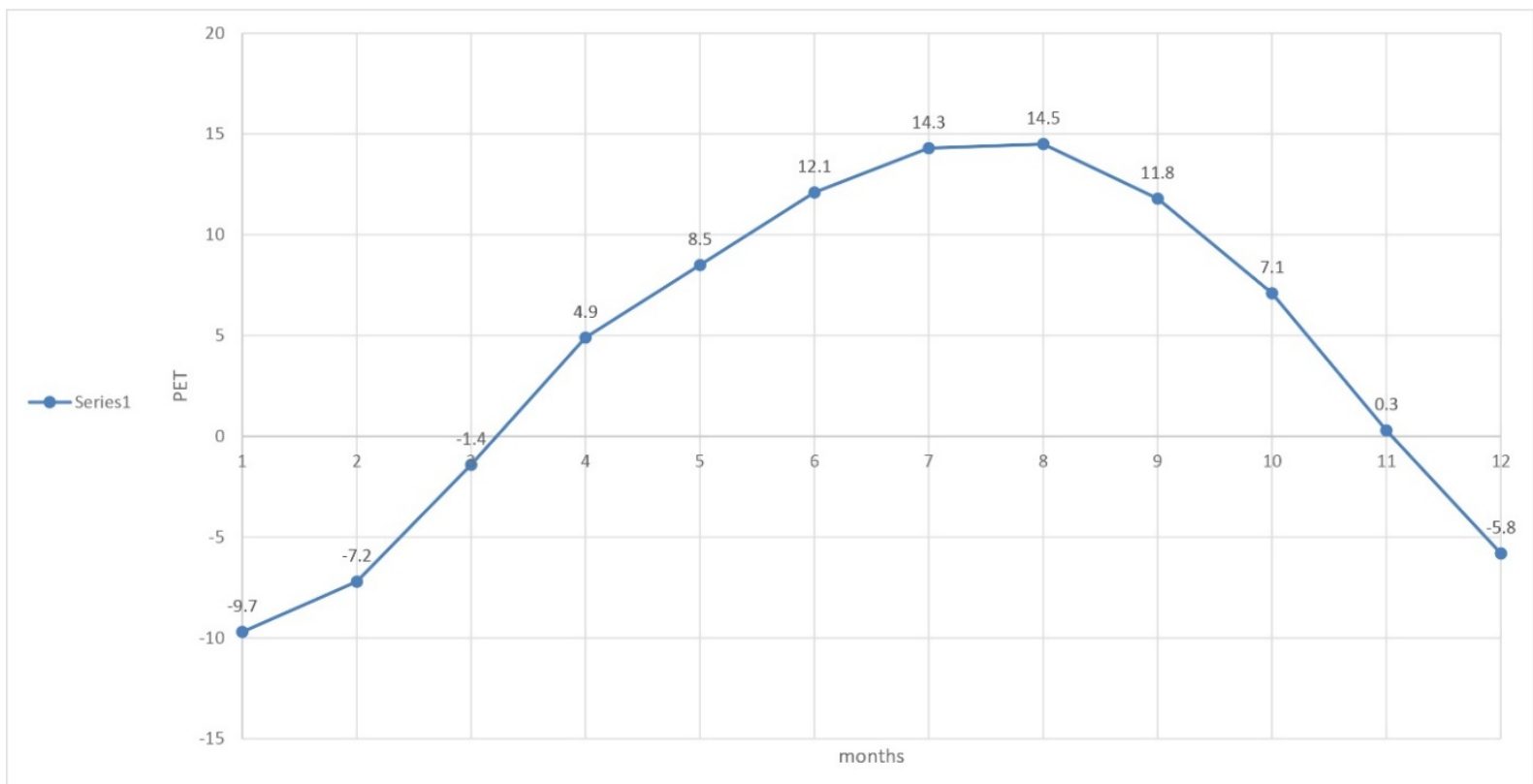

Figure 1. Long-term PET frequency(1976-2010)

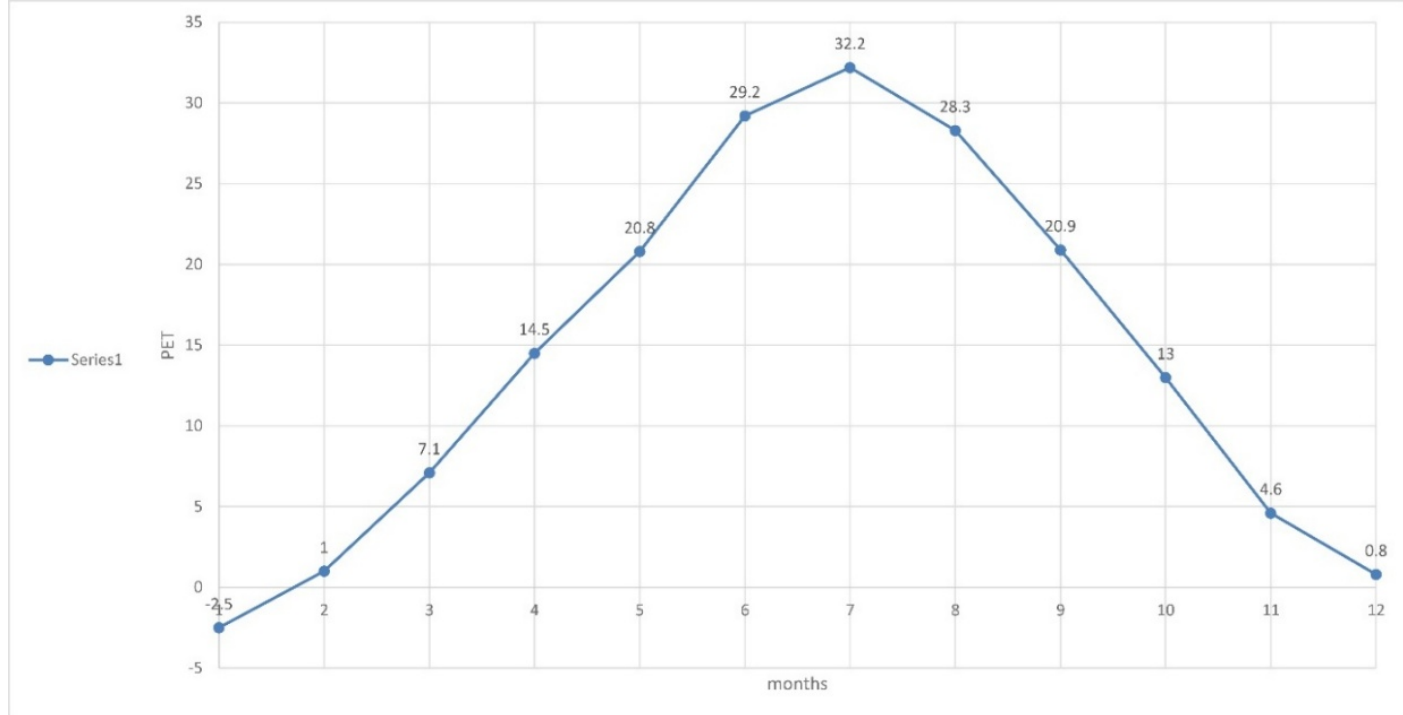

Figure 2. Long-term PET frequency (1967-2010)

\subsection{Selection of Typical Days}

Based on available information about the climate of Iran, and according to the meteorological report of Ardabil, the annual mean air temperature of the city is $9.22^{\circ} \mathrm{C}$ and the mean relative humidity is $72.33 \%$. The East wind $\left(90^{\circ}\right)$ is a prevailing local wind with $14.975 \mathrm{~m} / \mathrm{s}$ wind speed. Based on Ardabil meteorological organization reports, February, 2nd of 1989 was the coldest day in Ardabil with $-33.8^{\circ} \mathrm{C}$ of air temperature (Ardabilmet, 2016).

Accordingly, Yazd meteorological organization reports show that annual mean air temperature of Yazd is $19.21^{\circ} \mathrm{C}$ and mean relative humidity is 31.5 , and also the wind velocity is $8.016 \mathrm{~m} / \mathrm{s}$ with northwest $\left(315^{\circ}\right)$ prevailing direction. According to the Yazd meteorological organization reports, 13 July 2012 was the hottest day in Yazd with an air temperature of $45.6^{\circ} \mathrm{C}$. (Yazdmet, 2016). With this information, the thermal features of the two different climates of Iran will simulate in terms of better thermal comfort condition. The input data for 
simulation is presented in table 4 .

Table 4. Conditions used in the simulations with ENVI-met 4.

\begin{tabular}{|c|c|c|}
\hline Simulation parameters & Ardabil & Yazd \\
\hline Simulation day & 02.02 .1989 & 13.07.2012 \\
\hline Simulation period & $11 \mathrm{~h}(7: 00-18: 00)$ & $14 \mathrm{~h}(6: 00-20: 00)$ \\
\hline Spatial resolution & $1 \mathrm{~m}$ horizontally, $2 \mathrm{~m}$ vertically & $1 \mathrm{~m}$ horizontally, $2 \mathrm{~m}$ vertically \\
\hline Initial Temperature & 239.35 & 302.15 \\
\hline Wind speed & $3 \mathrm{~m} / \mathrm{s}$ & 2 \\
\hline Wind direction $(\mathrm{N}=0, \mathrm{E}=90)$ & 90 & 135 \\
\hline Relative humidity(in 2m) & $100 \%$ & $23 \%$ \\
\hline Indoor temperature & $300 \mathrm{~K}\left(27^{\circ} \mathrm{C}\right)$ & $293\left(20^{\circ} \mathrm{C}\right)$ \\
\hline $\begin{array}{l}\text { Initial Temperature Upper Layer }(0-20 \\
\mathrm{cm})\end{array}$ & 239 & 302.15 \\
\hline $\begin{array}{l}\text { Initial Temperature Middle Layer }(20-50 \\
\mathrm{cm})\end{array}$ & 232.15 & 300 \\
\hline $\begin{array}{l}\text { Initial Temperature Deep Layer (below } \\
50 \mathrm{~cm} \text { ) }\end{array}$ & 229.4 & 297.15 \\
\hline $\begin{array}{l}\text { Relative Humidity Upper Layer }(0-20 \\
\mathrm{cm})\end{array}$ & 100 & 23 \\
\hline $\begin{array}{l}\text { Relative Humidity Middle Layer (20-50 } \\
\mathrm{cm})\end{array}$ & 100 & 25 \\
\hline $\begin{array}{l}\text { Relative Humidity Deep Layer (below } \\
50 \mathrm{~cm} \text { ) }\end{array}$ & 100 & 28 \\
\hline Adjustment factor for solar radiation & 1 & 1 \\
\hline clouds & Default & Default \\
\hline Turbulence model & Use default values & Use default values \\
\hline LBC & For & For \\
\hline & Ta,RH:Open,turbulence;forced & Ta,RH:Open,turbulence;forced \\
\hline
\end{tabular}

\section{Literature Review}

\subsection{Thermal Comfort Analyses of Courtyards}

Courtyards are enclosed or semi-closed, open spaces housed in building environments, especially in the context of traditional architecture, which use vegetation and water to provide thermal comfort and to suit the microclimate to its inhabitants. Courtyard concept is a common method of local house designing in the Middle East, especially in Iran. (Almhafdy et al., 2013; Costello, 1977; Mirmoghtadaee, 2009; Ghaffarianhoseini et al., 2015).

The main function of courtyards in all countries is to modify the effect of climatic parameters on inhabitants and to create a suitable microclimate based on local climate. In different climates, different strategies are used to modify the rough environment. (Aldawoud, 2008). A courtyard concept with different features based on the local climate is one of the main principles of vernacular architecture (Coch, 1998). For example, the use of passive ventilation to avoid the annoying humidity in tropical and humid areas is the most significant feature of courtyards in these regions. (Rajapaksha et al., 2003; Sadafi et al., 2011; Makaremi et al., 2012). In hot and arid regions, modification of the environment by water, vegetation, etc., is the most common solution to modify the climatic parameters. (Etzion, 1990; Attia, 2006; Al-Hemiddi et al., 2001). Cold climates also have their own features to avoid annoying wind and to reach sun rays. (Shokouhian et al., 2007; Song et al., 2015; Zhang et al., 
2015).

The courtyard concept plays an important role in designing various public facilities such as education, residential areas, and healthcare facilities, but there are not enough strategies to enhance the thermal comfort of courtyards in the different climates of Iran. Uniform design of courtyards in diverse climates of Iran has caused lots of problems in terms of thermal comfort. Lack of sufficient knowledge of thermal characteristics of the courtyards is the main reason for this problem. Courtyards are mostly analyzed in terms of their airflow, solar radiation, and shadow features.

The ventilation potential of the courtyards and their effect on the thermal comfort has been evaluated by CFD studies and wind tunnels in various climates. (Mousli \& Semprini, 2015; Almhafdy et al., 2015; Jamaludin et al., 2014). Shade and its effect on the thermal comfort in courtyards are reported as being an important issue in developing the comfort range and energy consumption. (Meir et al., 1995; Yaşa \& Ok, 2014). Energy performance of courtyards has been investigated by many researchers (Aldawoud\& Clark, 2008; Muhaisen \& Gadi, 2006; Manioğlu \& Yılmaz, 2008; Dunham, 1961; Al-Masri \& Abu-Hijleh, 2012; Behbood et al, m2010; Safarzadeh \& Bahadori, 2005). Aldawoud et al discussed the energy performance of the courtyard and of atrium-based buildings. They proved that in general, the open courtyard shows a better energy performance for lower buildings. As building height increases, however, at some point, the enclosed atrium exhibits a better energy performance than the courtyard. With atrium research, some case studies depend on other factors such as glazing and climatic parameters. (Aldawoud \& Clark, 2008).

Courtyard proportions and their effect on heat gain and energy requirement were investigated in a Rome climate by Ahmed \& Muhaisen. The study, consequently showed that the proportions of the building that houses the courtyard considerably influence the need for heating and cooling. (Muhaisen \& Gadi, 2006). In the hot and arid climate of Iran, Behbood et al showed that courtyard method is one of the efficient strategies in terms of energy consumption (Behbood et al., 2010).

In another example of Iranian courtyard research, the passive cooling of courtyards has been investigated by the Safarzadeh et al, and they showed that a courtyard alone cannot make thermal comfort in Tehran, Iran but it can decrease the cooling energy load (Safarzadeh \& Bahadori, 2005). Hedari, in his Ph.D. thesis, investigated the thermal comfort in the courtyards of Ilam, Iran. The findings of the study revealed that the people in Ilam could achieve comfort at higher indoor air temperatures compared to the recommendations by international standards like ISO 7730. The results also showed that passive systems such as the main comfort strategy could be applied to housing design in Ilam. By using the results of this study, strategies to minimize energy consumption, not only for Ilam but also for other regions, which have similar climates and cultures to Ilam, can be proposed. (Heidari, 2000).

Taban et al tried to get an optimal courtyard pattern in Dezful by local shadow analysis, and they revealed that courtyards with a length/width ratio of 1 to 1.4 (near to square form) and height/length ratio of 1.1 to 1.2 had the most proper shade on different courtyard surfaces. Results also showed that for the purpose of reducing the cooling load in summer, deep and square-shaped courtyard forms were the most preferable. The self-shading of the courtyard building acts to reduce the need for cooling by an average of about $4 \%$. By using this proportion, the amount of shadows on the courtyard will be optimized (Taban et al., 2014). Modelling study showed that the effect of rectangular courtyard proportions on the shading and exposure conditions produced on the internal envelope of the form in four different locations in Kuala Lumpur, Cairo, Rome and Stockholm and the results showed that the shading conditions of the courtyard internal envelopes are significantly dependent on the form's proportions, location latitude, and available climatic conditions. (Muhaisen, 2006).

A study by Taleghani et al, analyzed the energy performance and thermal comfort of the Netherlands with the light climate changes of this country. The results of this research, which analyzed monthly energy performance, comfort hours and climate scenarios, indicated that using an open courtyard from May through October and an atrium, i.e. a covered courtyard, in the rest of the year establishes an optimum balance between energy use and summer comfort for the severest climate scenario. (Taleghani et al., 2014).

Al-Masri et al, evaluated the courtyard housing in mid-rise buildings of Dubai, United Arab Emirates. In this study, the courtyards have been assessed in terms of energy consumption and daylight factors, and the result of this study shows that the energy consumption of the optimal courtyard is $11.16 \%$ less than conventional form building and about the daylight factor. In the courtyard form in both winter and summer time, the courtyard has a better thermal condition. (Al-Masri et al., 2012). The effect of a courtyard's shape and geometry on heat gain and energy efficiency in various climates has been assessed by Yaşa\& Ok. In this study, the optimal shape of the courtyard was presented by CFD Fluent (Yaşa \& Ok, 2014). 
Climatic variables and their effect on thermal comfort are discussed by Sthapak \& Bandyopadhyay. In this study, in addition to the placement of the rooms and the proportion of the openings, the degree of enclosure of the courtyards and also the breeze and shadow effect on thermal comfort - especially in light time - are scrutinized. (Sthapak \& Bandyopadhyay, 2014). Because of the diverse climate of Iran, new bioclimatic research has been done by Pourvahidi \& Ozdeniz. In this study, the bioclimatic conditions of Iranian cities were determined and as a result; five climates were identified in Iran.

In order to prove that this new classification is valid, the traditional architecture of these regions was juxtaposed. It turned out that the traditional buildings have different features in these five regions. (Pourvahidi\&Ozdeniz, 2013). A study of the environmental effect of the residential building courtyards in different climates was done by Taleghani et al, The findings of these studies show that the different configurations of courtyard buildings, such as natural elements, and the situation of openings in different facades are the most important findings of this review paper. (Taleghani et al., 2012).

Recently some studies have examined the comfort condition of the courtyards as a house and urban forms (Ghaffarianhoseini et al., 2015; Taleghani et al., 2015; Berkovic et al., 2012; Taleghani et al., 2014). Comfort condition of the courtyards is simulated by ENVI-met model software using the PMV thermal index and in this study, Berkovic et al presented the design guidelines for courtyards in Israel and compared various courtyard geometries and shading using trees, openings, and galleries (Berkovic et al., 2012). Cooling strategies of Netherlands courtyard were investigated by a parametric study, and results of this paper demonstrate three heat mitigation strategies for the urban courtyard. ENVI-met was validated for the Netherlands with measurement. (Taleghani et al., 2014).

In another study of the thermal characteristic of the courtyard in a hot and humid climate of Tainan, Taiwan, by Yang et al, the results of this study showed that the integrated design approach can effectively reduce the frequency of heat stress from $79.7 \%$ to $40.5 \%$ and it is noticeable that by this study, the potential and limitations of the ENVI-met model, is applied in tropical climates (Yang et al., 2016). Thermal assessment of the Portland university courtyard is done by Taleghani et al, in this study, heat mitigation strategies in this university were examined by ENVI-met model and the results showed that the maximum PCI effect was $5.8^{\circ} \mathrm{C}$ between a park and a parking lot. Vegetation and a water pond reduced $1.6^{\circ} \mathrm{C}$ and $1.1{ }^{\circ} \mathrm{C}$ Ta for a bare courtyard, and finally, high albedo material increased Tmrt but reduced Ta. (Taleghani et al, 2014). The study by Ghaffarianhoseini et al, tries to represent the optimal forms of the courtyard in Malaysia. These courtyards have been examined by four parameters of orientation, vegetation, albedo, and height. Consequently, they have evaluated the optimal choice of these parameters represented by ENVI-met simulation for the Malaysian courtyards (Ghaffarianhoseini et al., 2015). Taleghani et al examined the five urban forms of the Netherlands and the final results show that the courtyard form is the best form in terms of PET, Tmrt,... in the moderate climate of the Netherlands (Taleghani et al., 2015).

\subsection{Calculation of PET as Thermal Comfort Index}

The physiological equivalent temperature, PET, is a thermal index derived from the human energy balance. It is well suited to the evaluation of the thermal component of different climates, as well as having a detailed physiological basis (Prata-Shimomura et al., 2009).

The PET index is often used in environmental comfort research for analyzing the physiological behavior of users and pedestrians, according to environmental conditions (effect of buildings and climate). (Matzarakis et al., 1999). PET as thermal comfort has been used in several studies of outdoor thermal comfort (Thorsoson et al., 2007; Andrade \& Alcoforado, 2007; Oliveria \& Andrade, 2007; Johansson, 2006; Emmanuel \& Johansson, 2006) because the PET index has been primarily designed for outdoor use (Spagnolo \& Dear RJ, 2003). PET can be calculated using free software (Rayman). This software is validated software for urban complex shading (Lin et al., 2006; Gulyas et al, 2006; Matzaraki et al., 2007). Environmental data for the PET calculation that is required in the Rayman model includes air temperature $\left(\mathrm{T}_{\mathrm{a}}\right.$ ), relative humidity ( $\mathrm{RH} \%$ ), wind velocity (v), mean radiant temperature (Tmrt) and vapor pressure (VP) and personal data such as human clothing and activity and local data such as the date of year, time and location. Comfort classification of PET scale is described by below table 1 .

\section{Results and Discussion}

\subsection{Reliability of ENVI-met4}

In this step, ENVI-met model (the courtyard shape as a sample) was validated through a comparison between field measurements and simulation results. The measurements were done in a courtyard building representing a traditional house of Ardabil and Yazd. Manafzadeh house in Ardabil and German house in Yazd were selected to 
assess the reliability and calibration of ENVI-met4. For this assessment, two different days in two different climates of Iran were selected. The air temperature sensor was protected by a white shield to minimize the effect of the radiation. The courtyards' environments were measured for 11 days in February for Ardabil and June for Yazd.

Among these 11 days, two days for each city were selected randomly for Envi-met simulation. February $5^{\text {th }}$ and $13^{\text {th }}$ of 2015 and June $15^{\text {th }}$ and $23^{\text {rd }}$ of 2015 were the random days. The weather data for the simulation process were taken from the local weather station. The data from simulations and measurements are compared to show the accuracy of the simulation results. To do this simulation, an Envimet Area input file and configuration files are needed. The input-file are described in table 5 and 6.

Table 5. Ardabil configuration data for ENVI-met4 validation

\begin{tabular}{ccc}
\hline Simulation parameters & Ardabil & Ardabil \\
\hline Simulation day & 05.02 .2015 & 13.02 .2015 \\
Simulation period & $24 \mathrm{~h}(21: 00-21: 00)$ & $24 \mathrm{~h}(21: 00-21: 00)$ \\
Spatial resolution & 1m horizontally,2m vertically & $1 \mathrm{~m}$ horizontally,2m vertically \\
Initial Temperature & 273.15 & 272.15 \\
Wind speed & $3 \mathrm{~m} / \mathrm{s}$ & $9 \mathrm{~m} / \mathrm{s}$ \\
Wind direction (N=0,E=90) & 45 & 225 \\
Relative humidity(in 2m) & $100 \%$ & $100^{\circ}$ \\
Indoor temperature & $300 \mathrm{~K}\left(27^{\circ} \mathrm{C}\right)$ & $300 \mathrm{~K}\left(27^{\circ} \mathrm{C}\right)$ \\
Initial Temperature Upper Layer (0-20 cm) & 273.15 & 272.15 \\
Initial Temperature Middle Layer (20-50 & 269.45 & 269.45 \\
cm) & & 264.15 \\
Initial Temperature Deep Layer (below 50 & 265.15 & 100 \\
cm) & 100 & 100 \\
Relative Humidity Upper Layer (0-20 cm) & 100 & 100 \\
Relative Humidity Middle Layer (20-50 cm) & 100 & 1 \\
Relative Humidity Deep Layer (below 50 & Ta,RH:Open,turbulence;forced & Ta,RH:Open,turbulence;forced \\
cm) & Default & Default \\
Adjustment factor for solar radiation & Use default values & Usefault values \\
clouds & &
\end{tabular}


Table 6. Yazd configuration data for ENVI-met4 validation

\begin{tabular}{|c|c|c|}
\hline Simulation parameters & Yazd & Ardabil \\
\hline Simulation day & 15.06 .2015 & 23.06 .2015 \\
\hline Simulation period & $24 \mathrm{~h}(21: 00-21: 00)$ & $24 \mathrm{~h}(21: 00-21: 00)$ \\
\hline Spatial resolution & $1 \mathrm{~m}$ horizontally, $2 \mathrm{~m}$ vertically & $1 \mathrm{~m}$ horizontally, $2 \mathrm{~m}$ vertically \\
\hline Initial Temperature & 301.15 & 305.15 \\
\hline Wind speed & $5 \mathrm{~m} / \mathrm{s}$ & $1 \mathrm{~m} / \mathrm{s}$ \\
\hline Wind direction $(\mathrm{N}=0, \mathrm{E}=90)$ & 135 & 0 \\
\hline Relative humidity(in $2 \mathrm{~m}$ ) & $10.80 \%$ & $8.5 \%$ \\
\hline Indoor temperature & $300 \mathrm{~K}\left(27^{\circ} \mathrm{C}\right)$ & $300 \mathrm{~K}\left(27^{\circ} \mathrm{C}\right)$ \\
\hline Initial Temperature Upper Layer $(0-20 \mathrm{~cm})$ & 301.15 & 239 \\
\hline Initial Temperature Middle Layer $(20-50 \mathrm{~cm})$ & 298.15 & 298.15 \\
\hline Initial Temperature Deep Layer (below $50 \mathrm{~cm}$ ) & 295.45 & 229.4 \\
\hline Relative Humidity Upper Layer (0-20 cm) & $10.80 \%$ & $8.5 \%$ \\
\hline Relative Humidity Middle Layer (20-50 cm) & $12 \%$ & $10 \%$ \\
\hline \multicolumn{3}{|l|}{ Relative Humidity Deep Layer ( } \\
\hline & $15 \%$ & $13 \%$ \\
\hline \multicolumn{3}{|l|}{$50 \mathrm{~cm})$} \\
\hline Adjustment factor for solar radiation & 1 & 1 \\
\hline clouds & Default & Default \\
\hline Turbulence model & Use default values & Use default values \\
\hline \multirow{2}{*}{ LBC } & For & For \\
\hline & Ta,RH:Open,turbulence;forced & Ta,RH:Open,turbulence;forced \\
\hline
\end{tabular}

For configuration file, four extra courtyard models have been modeled to reach the correct results in terms of the neighboring environment on the courtyard affects the output data, so accordingly the surrounding vegetation, pavement, and other real parameters are included in the simulation model. The measured and simulated Ta during the mentioned days in both cities are compared in Fig3 and 4. 


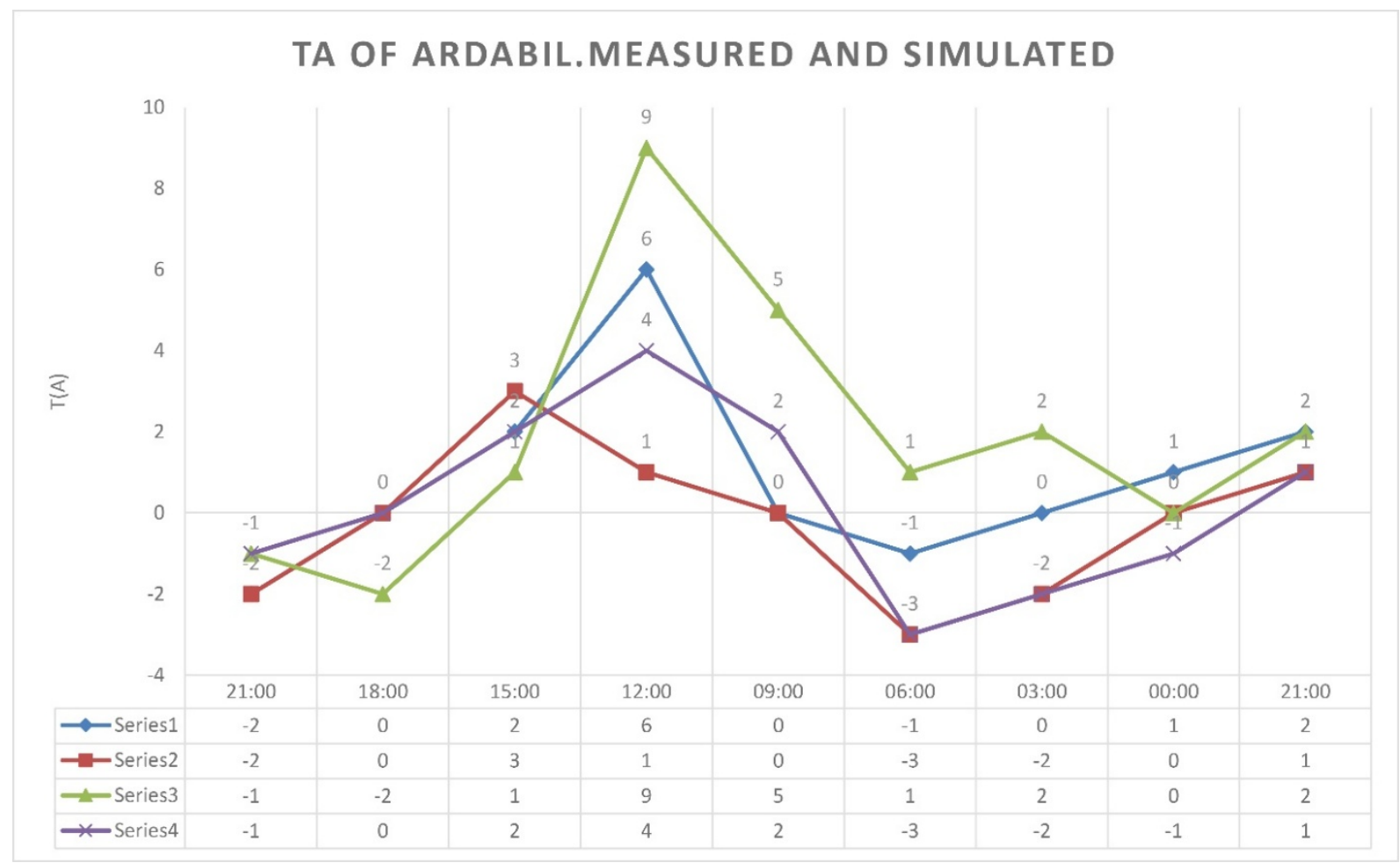

Figure 3. Comparison of measured and simulated Ta in Ardabil

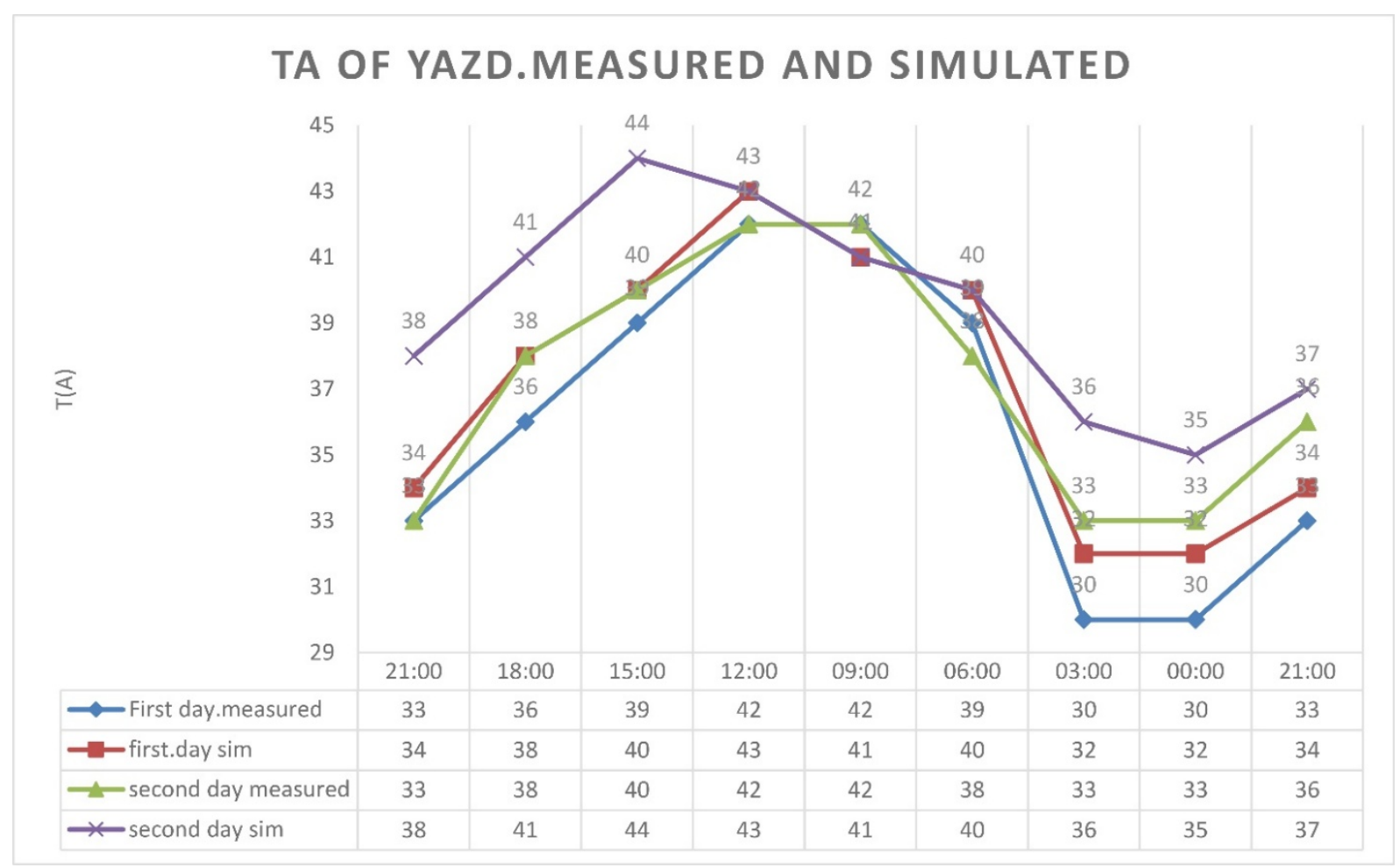

Figure 4. Comparison of measured and simulated Ta in Yazd

Comparisons of the air temperature in both cities show that correlation of measured and simulated Ta in the first day in Ardabil is $82 \%(\mathrm{R}=0.82)$, and also $\mathrm{R}$-value for the second day is 0.88 . Therefore, on average, the correlation factor is 0.71 which means that more than $88 \%$ of ENVI-met outputs are reliable in the cold climate of Ardabil. Correlation analyses of simulated and measured air temperature in Yazd represent the high correlation 
between simulated and measured Ta. The first-day's R-value is 0.98 , and for the second day, it is 0.87 . Therefore, ENVI-met outputs are completely reliable in the hot, arid climate of Yazd. The difference in the observed and simulated data could be the fact that ENVI-met does not include levels of cloudiness in its input parameters.

\subsection{Physical Features of Traditional Courtyards of Ardabil \& Yazd}

4.2.1Ardabil Traditional Courtyards

In this section, traditional courtyards of Ardabil were selected to be assessed in terms of physical features:

(i) The ratio of the courtyard area to total area of the house

(ii) The ratio of the water area to total area of the courtyard

(iii) The ratio of the vegetation area to total area of the courtyard

For this study, 8 traditional courtyards were selected to be investigated:

(i) Khadem house.

(ii) Sadeghi house.

(iii) Vakil Al-Roaya house

(iv) Reza Zadeh house.

(v) Ershadi House.

(vi) Ebrahimi House.

(vii) ManafZadeh House

(viii) Khalil Zadeh house.

Table 7. Physical features of Ardabil courtyard

\begin{tabular}{cccc}
\hline $\begin{array}{c}\text { Vegetation area/ } \\
\text { courtyard }\end{array}$ & $\begin{array}{c}\text { Water } \\
\text { area/courtyard area }\end{array}$ & $\begin{array}{c}\text { Total } \\
\text { area/courtyard area }\end{array}$ & House name \\
\hline 0.5 & 0.04 & 0.51 & Khadem house \\
0.36 & 0.03 & 0.48 & Sadeghi house \\
0.00 & 0.00 & 0.22 & Vakil Al-roaya house \\
0.43 & 0.02 & 0.51 & Reza Zadeh house \\
0.00 & 0.00 & 0.22 & Ershadi House \\
0.18 & 0.05 & 0.36 & Ebrahimi House \\
0.37 & .03 & 0.60 & ManafZadeh House \\
0.09 & 0.02 & 0.46 & .Khalil Zadeh house \\
\hline
\end{tabular}

\subsubsection{Yazd Traditional Courtyards}

In the second step, these 8 Yazd traditional courtyards were also selected to be assessed for the mentioned features:

(i) MehrabanGoodarz house

(ii) Lariha house

(iii) Gerami house

(iv) Golshan-e-Yazd house

(v) Kolahdoozha house

(vi) Arabha house

(vii)Mortaz house

(viii) Rasoulian house

The mentioned features were described in Table 8: 
Table 8. Physical features of Ardabil courtyard

\begin{tabular}{cccc}
\hline $\begin{array}{c}\text { Vegetation area/ } \\
\text { courtyard }\end{array}$ & $\begin{array}{c}\text { Water } \\
\text { area/courtyard area }\end{array}$ & $\begin{array}{c}\text { Total } \\
\text { area/courtyard area }\end{array}$ & House name \\
\hline 0.08 & 0.04 & 0.16 & MehrabanGoodarz house \\
0.19 & 0.12 & 0.21 & Lariha house \\
0.23 & 0.15 & 0.24 & Gerami house \\
0.15 & 0.21 & 0.22 & Golshan-e-Yazd house \\
0.20 & 0.15 & 0.26 & Kolahdoozha house \\
0.10 & 0.10 & 0.25 & Arabha house \\
0.25 & 0.14 & 0.38 & Mortaz house \\
0.10 & 0.17 & 0.30 & Rasoulian house \\
\hline
\end{tabular}

\subsubsection{Comparison}

In a comparison of the data derived from the previous tables, it can be concluded that in Yazd's hot-arid climate, due to a long and hotter summer, more water ponds were used. This is in contrast with the rough, cold climate of Ardabil where only a small area of water covers the courtyard. In terms of vegetation, a smaller area of courtyards in Yazd is covered by trees to reach optimum natural ventilation. In Ardabil's cold climate, this percentage is more than Yazd. About total area of the courtyard in these two contrasting climates, the averages of the courtyard is about $42 \%$ of the total plan and $0.26 \%$ of the total plan consider as a courtyard. In table 9 , a comparison of these mentioned features is portrayed:

Table 9. Comparison of the physical features of both climate

\begin{tabular}{cccc}
\hline $\begin{array}{c}\text { Vegetation area/ } \\
\text { courtyard }\end{array}$ & $\begin{array}{c}\text { Water } \\
\text { area/courtyard area }\end{array}$ & $\begin{array}{c}\text { Total } \\
\text { area/courtyard area }\end{array}$ & city \\
\hline 0.23 & 0.03 & 0.42 & Ardabil \\
0.18 & 0.14 & 0.26 & Yazd \\
\hline
\end{tabular}

\subsection{Results of Simulations}

The study scrutinized different courtyard configurations. The sample building and its courtyard dimension were chosen by the average of the real traditional courtyard houses of Ardabil and Yazd. The $360 \mathrm{~m}^{2}(60 * 60 \mathrm{~m}) 2$-story building ( 8 meters of height) and the other parameters of the courtyard (dimension, water amount, and the vegetation) were selected based on the minimum and maximum of the real courtyard houses of the Ardabil and Yazd.

\subsubsection{Effect of the Courtyard Area}

As a first step, it is crucial to determine the courtyard area percentage based on local climate. So, in this regard, $10,20,40$ and 60 percent of the block was considered as a courtyard and simulated for both climates.

The impact of the different areas towards influencing the microclimate features such as relative humidity, wind velocity, Tmrt, and the ambient temperature were measured recording the different factors on the values assumed by previous parameters in the center of the courtyard spaces.

\subsubsection{Ardabil Courtyard Area}

A comparison of the courtyards in terms of the area shows that the average air temperature in all four conditions is stable, and is about -11 . The differences between the highest and the lowest one is $0.4{ }^{\circ} \mathrm{C}(10 \%=-11.475,20=$ $-11.656,40 \%=-11.856$ and $60 \%=-11.906)$. However in terms of Tmrt, there is a different condition. The difference between the highest and the lowest is $11.73^{\circ} \mathrm{C}$. The hourly frequency of Tmrt is described in Fig 5 . Based on this Fig, (in all conditions) at the beginning of the morning (7.00-8:00 am) Tmrts are in the equal range. This is also true for the end of day (16.00-18:00 pm), but in the next hours, Tmrt of $60 \%$ area grows more quickly than the others, which means that the average air temperature of the Tmrt for $60 \%$ is higher than the 
others $\left(10 \%=24.58^{\circ} \mathrm{C}, 20 \% 35.84^{\circ} \mathrm{C}, 40 \%=35.22^{\circ} \mathrm{C}, 60 \%=36.31^{\circ} \mathrm{C}\right)$.

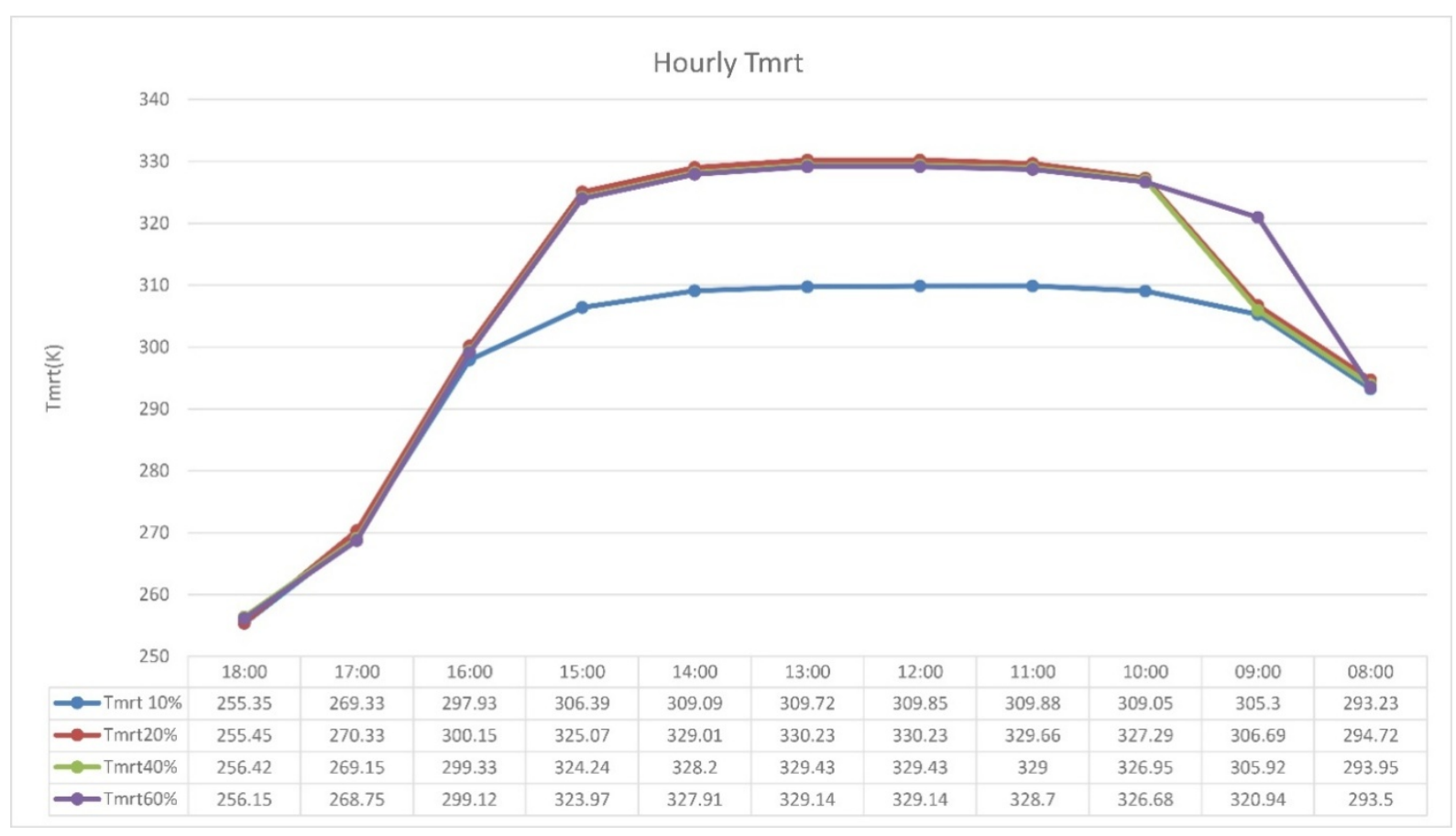

Figure 5.Hourly frequency of Tmrt of Ardabil

Wind velocity is another important parameter of outdoor thermal comfort and was also investigated in these courtyards. There were not any significant differences between the conditions in terms of average wind speed. On average, there is a $0.251 \mathrm{~m} / \mathrm{s}$ difference between the highest and the lowest velocity $(10 \%=3.958 \mathrm{~m} / \mathrm{s}$, $20 \%=3.881,40 \%=3.763$ and $60 \%=3.701 \mathrm{~m} / \mathrm{s}$ ).

The average figures for the PET values in these courtyards demonstrates 3-degree differences $\left(10 \%=-13.1{ }^{\circ} \mathrm{C}\right.$, $20 \%=-11.6,40 \%=-10.9,60 \%=-10.6)$ between all conditions. The $60 \%$ courtyard has a better condition, and because of its open sky condition, the $60 \%$ courtyard reaches longer direct and diffuse radiation and by this means R-value (correlation) between PET value and Tmrt, SW.dir, SW.diff are 0.915, 0.9, and 0.8715.

Hourly frequency of PET is described in Fig6. In FIG7, Leonardo visualization describes the Tmrt and wind speed conditions in a different configuration. 


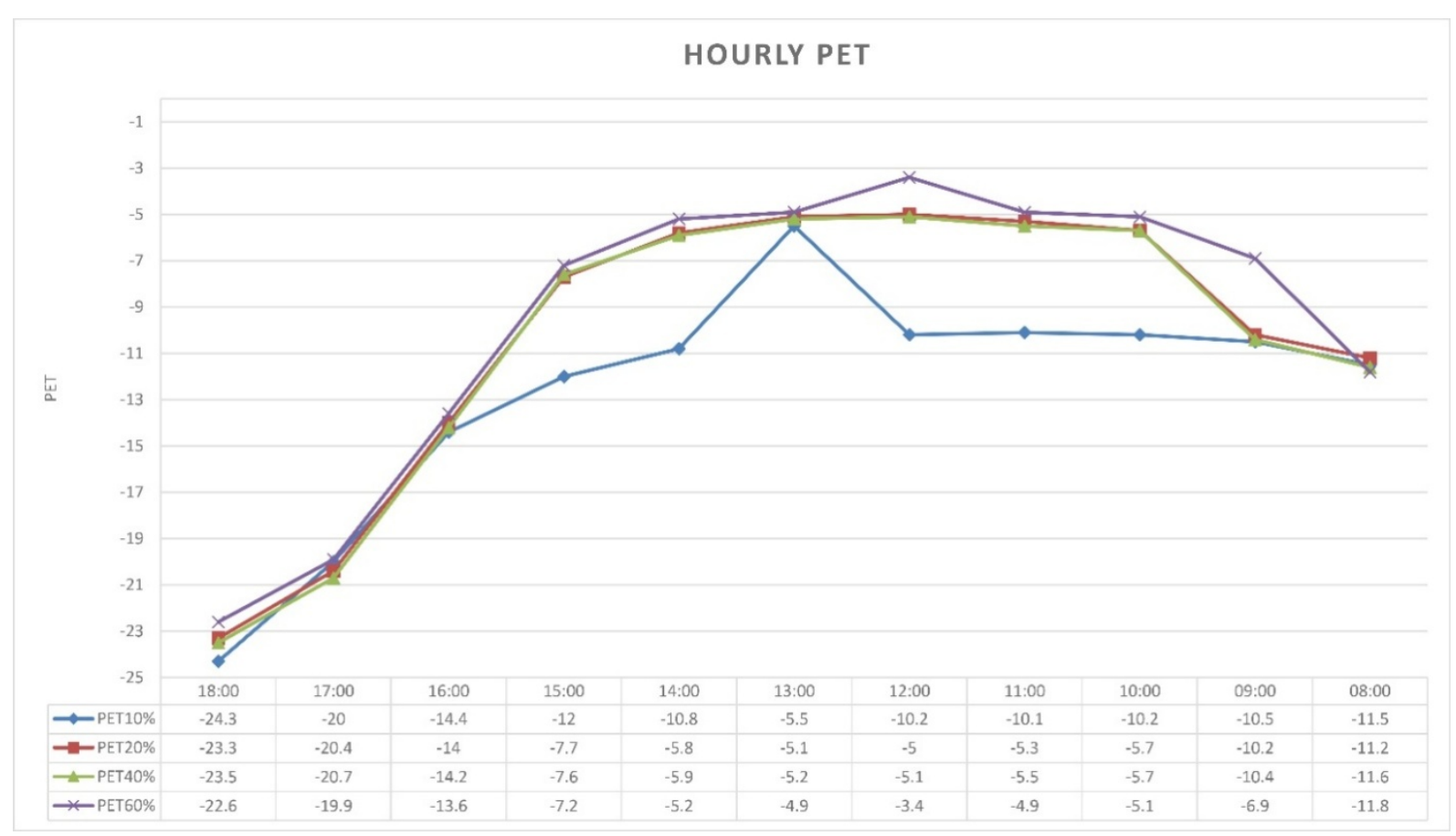

Figure 6. Hourly frequency of PET based on area. Ardabil 

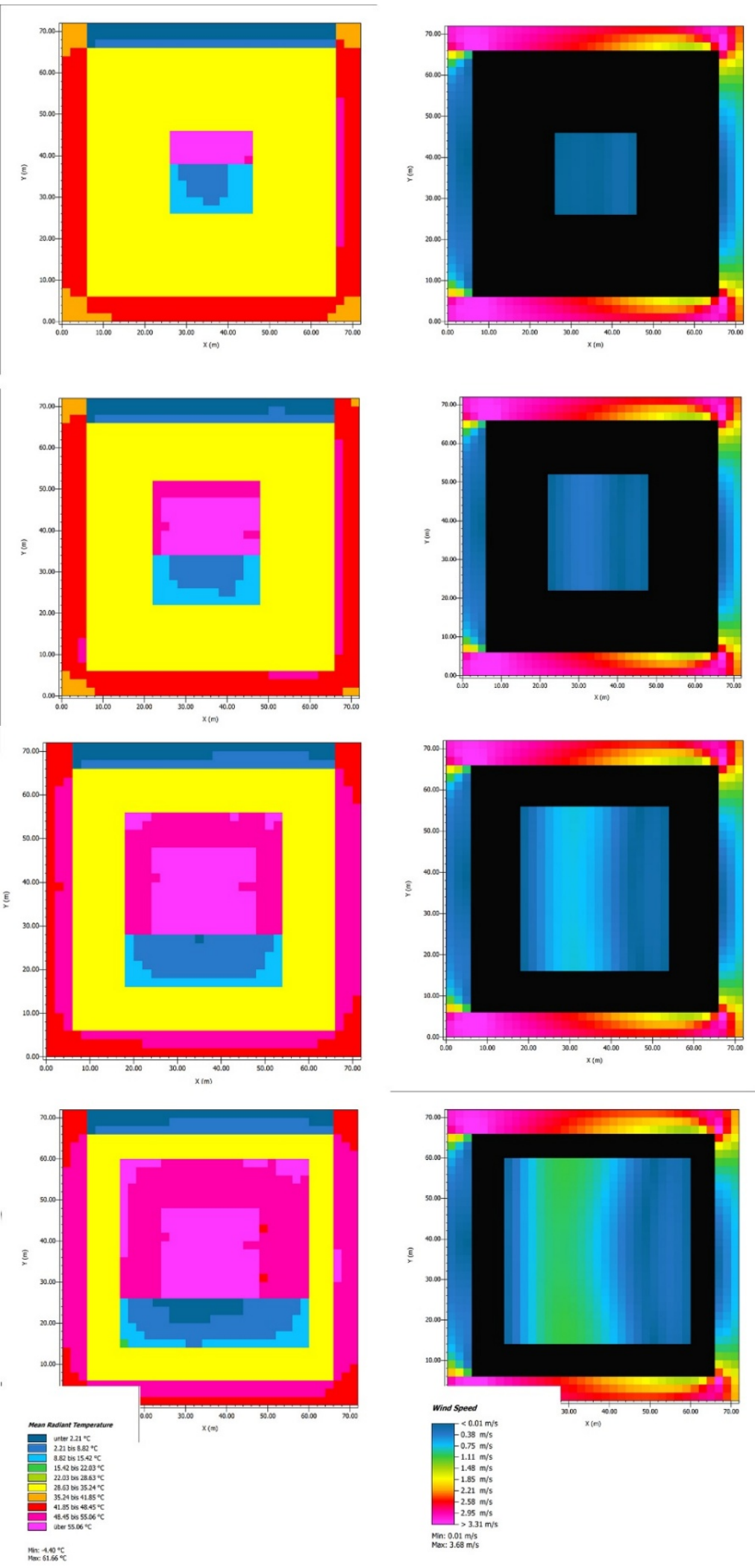

Figure 7. Tmrt and Wind speed condition of Ardabil courtyard (Leonardo) 


\subsubsection{Yazd Courtyard Is}

The courtyards were compared with their related Ta and the results show that there are not that many differences between the courtyards $\left(10 \%=24.89^{\circ} \mathrm{C}, 20 \%=24.92,40 \%=24.94,60 \%=25^{\circ} \mathrm{C}\right)$. However, the different sky exposure means that the Tmrt values are different, and by this means there are $3.17^{\circ} \mathrm{C}$ differences between the maximum and the minimum Tmrt. The hourly frequency of Tmrt is described in Fig 8. Based on this Fig, in all conditions, at the beginning (7.00-8:00 am) of the morning, the mean radiant temperature values are in the equal range but as the sun rises the radiation amount increase too.

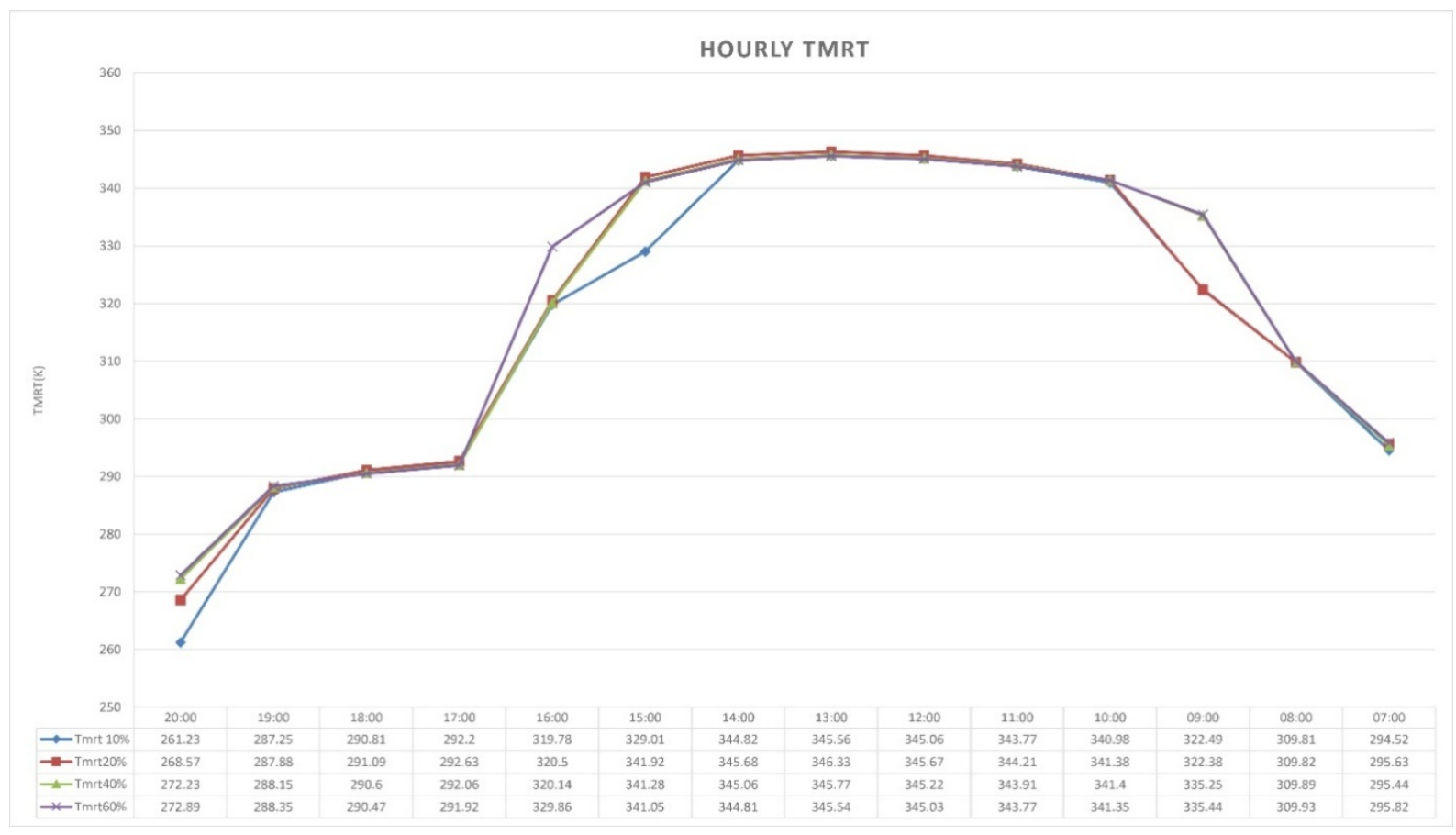

Figure 8. Hourly frequency of Tmrt of Yazd

In the next few hours, the $60 \%$ courtyards' Tmrt grows, quicker than the other courtyards'. Based on the graph, the thermal behavior of all conditions between 10:00-14:00 are equal, but the 10\% courtyard loses its Tmrt faster than the others and at the end of the day (20:00) it reaches the lowest Tmrt among the courtyards. Therefore, on average, the $10 \%$ courtyard has the lowest $\operatorname{Tmrt}\left(10 \%=52.69^{\circ} \mathrm{C}, 20 \%=54.26,40 \%=55.08,60 \%=55.86^{\circ} \mathrm{C}\right)$.

The average PET value in each courtyard represents a $1.8^{\circ} \mathrm{C}$ difference $\left(10 \%=31.4{ }^{\circ} \mathrm{C}, 20 \%=32.2,40 \%=32.6\right.$. $60 \%=33.2$ ) between all conditions. The $10 \%$ courtyard has a better condition, and because of the closer sky condition of the $60 \%$ courtyard, it reaches less long direct and diffuse radiation. This means the $\mathrm{R}$ values (correlation) between PET value and Tmrt, SW.dir, and SW.diff are 0.95, 0.94, and 0.96. The hourly frequency of related PET is described by Fig9. In FIG 10, Leonardo visualization describes the Tmrt and wind speed conditions in a different configuration. 


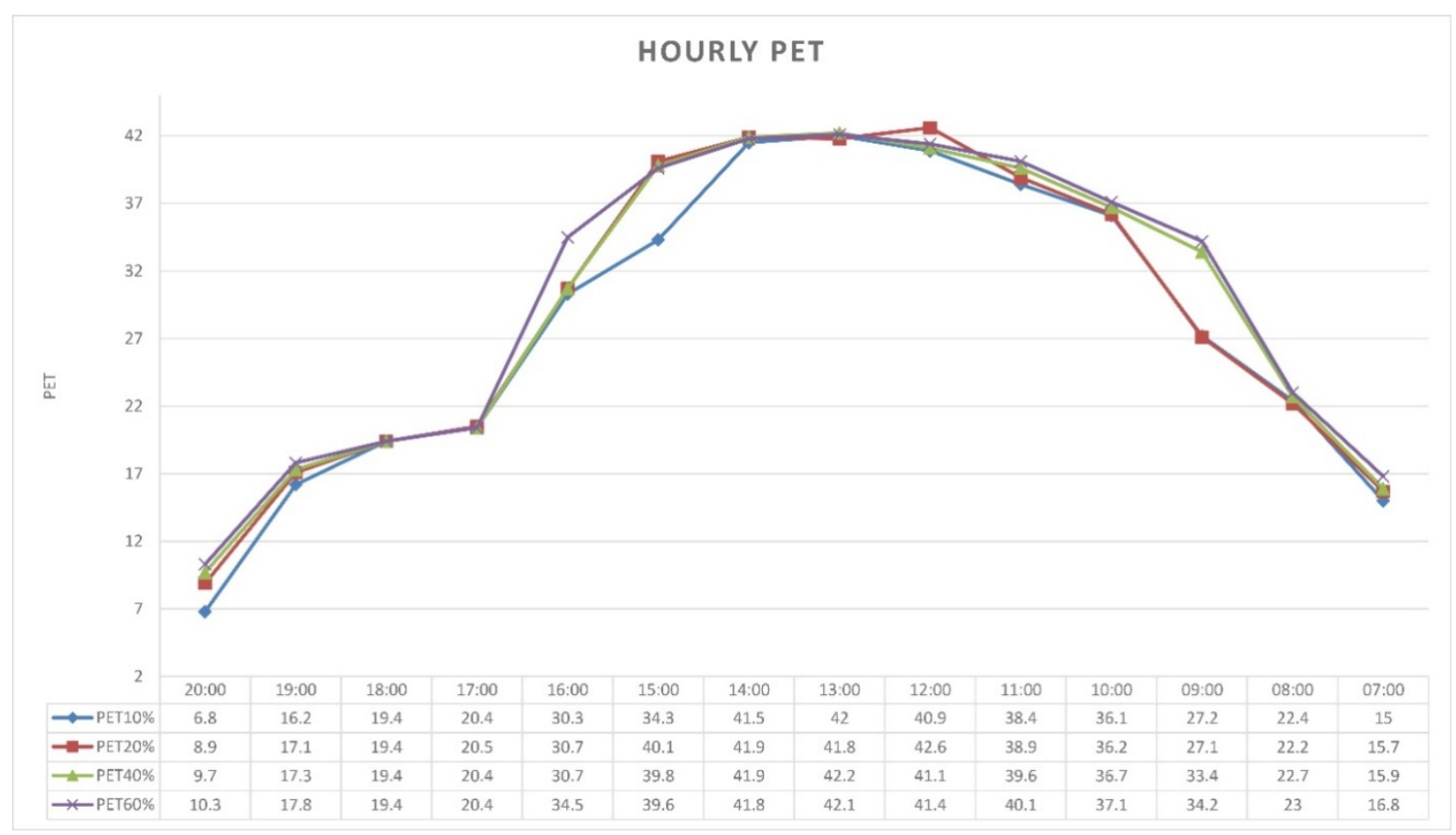

Figure 9. Hourly frequency of PET based on area.Yazd 

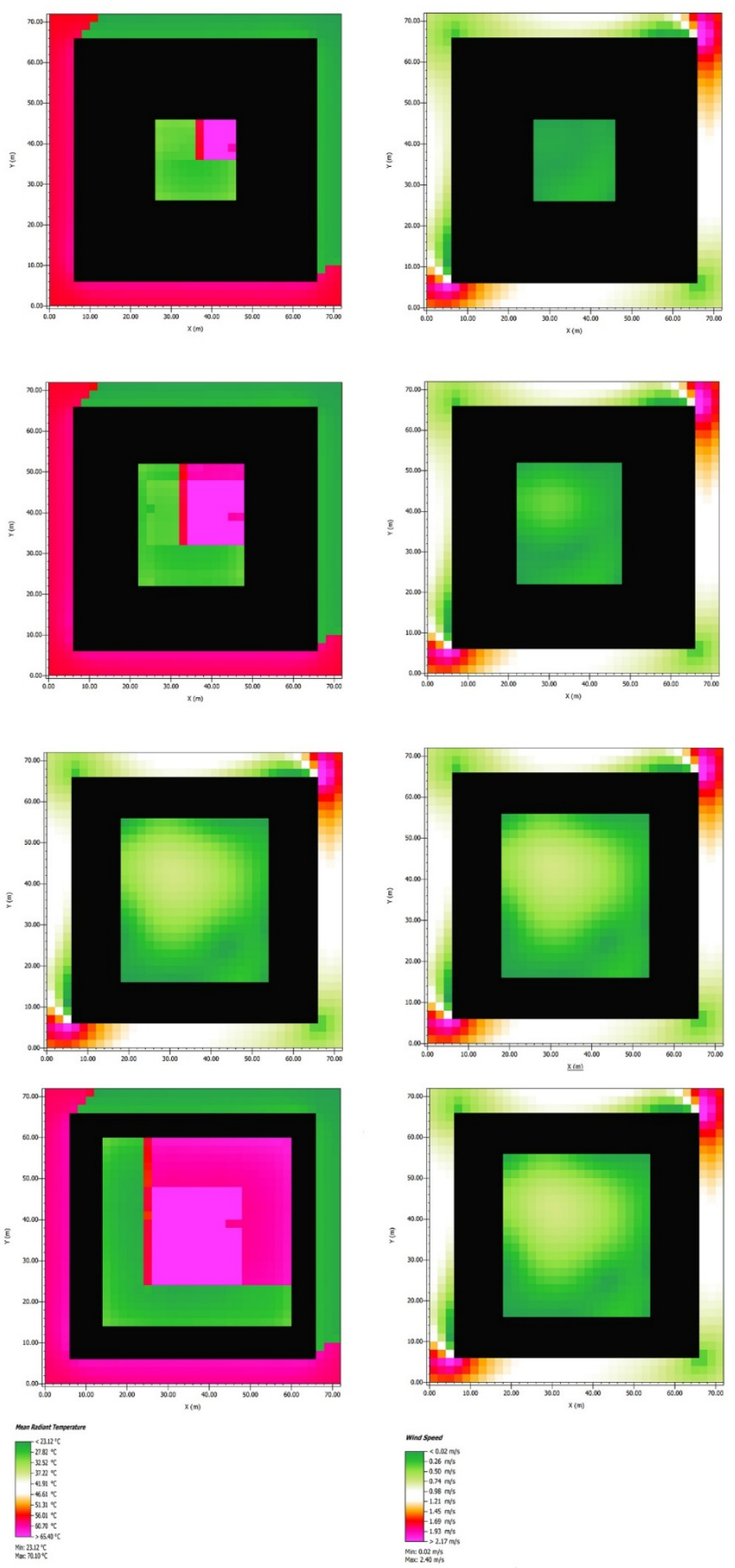

Figure 10. Tmrt and Wind speed condition of Yazd courtyard(Leonardo) 


\subsubsection{Effect of Courtyard Water Level}

The presence of water in Iranian traditional courtyards is a common principle, and water is also the main component of contemporary courtyards. This means that $0,10,15$, and 20 are the typical percentages of water in traditional courtyard areas in both climates. In this regard, these percentages have been considered as a courtyard and simulated for both climates.

The impact that different water amounts have upon microclimate features such as relative humidity and Tmrt was considered when recording the different factors for the values assumed by previous parameters in the center of the courtyard spaces.

\subsubsection{Ardabil Water Amount Analyze}

A comparison of the water level in the $60 \%$ area highlights the fact that air temperatures are in a roughly equal range $\left(0 \%=-12.26^{\circ} \mathrm{C}, 10 \%=-12.33,15 \%=-12.36,20 \%=-11.62\right)$. It also demonstrates that owing to the cold air temperature, the relative humidity of these conditions is $100 \%$, and, accordingly, the wind speed parameter is equal to all conditions. Radiant temperatures differ notably with different water amounts. The courtyard contains $0 \%$ water featured $10^{\circ} \mathrm{C}$ higher on the Tmrt scale $\left(0 \%=36.49^{\circ} \mathrm{C}, 10 \%=26.24,15 \%=26.26,20 \%=26.56\right)$, and the hourly frequency of the Tmrt is described in Fig11.

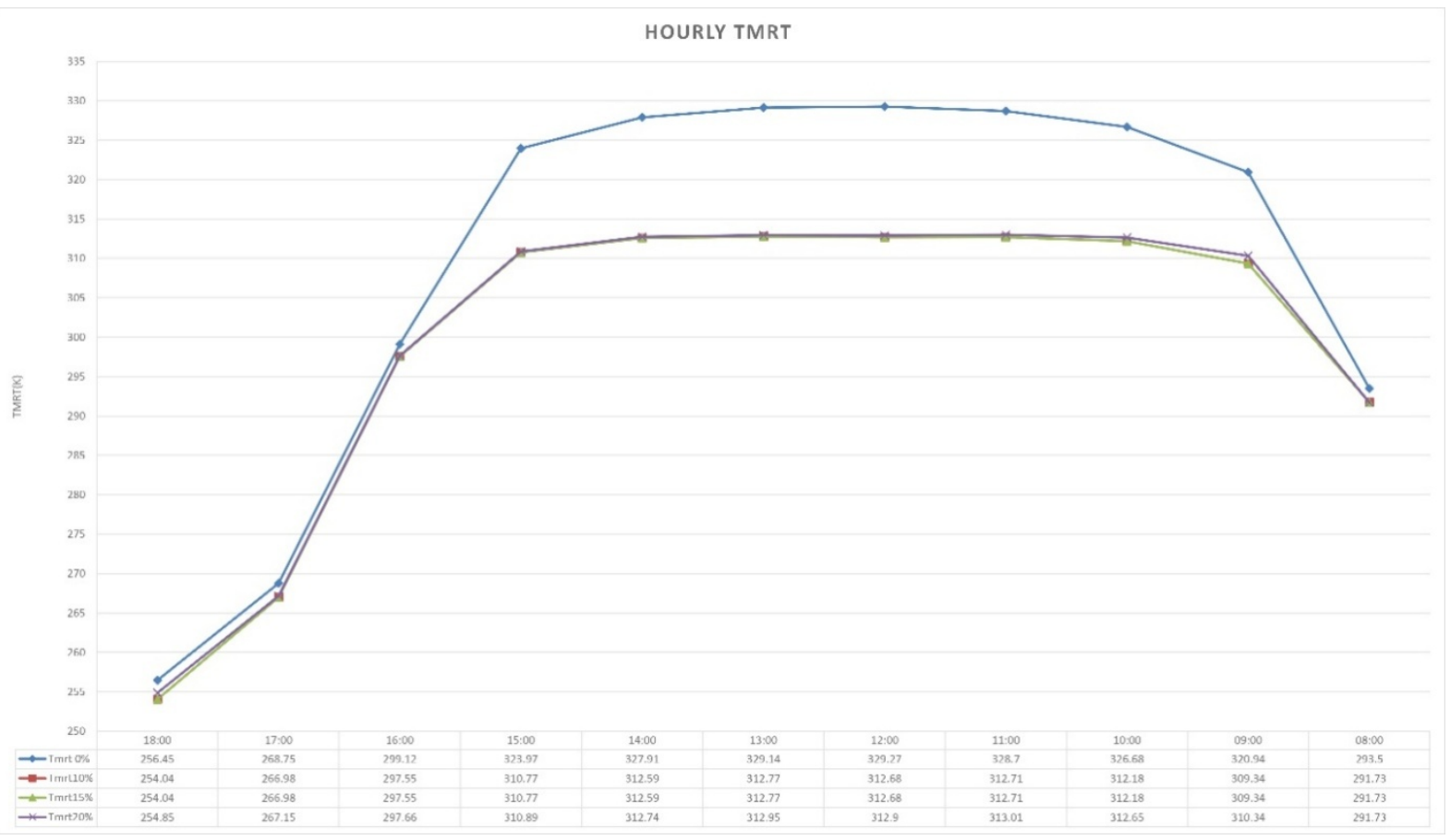

Figure 11. Hourly frequency of Tmrt(water amount)

According to the seven, all other conditions except the $0 \%$ have a colder Tmrt. At the beginning of the referenced day (7.00-8:00 am), all conditions have equal Tmrt but by sunrise, the thermal behavior of the courtyards changes - the courtyard containing no water reaches the highest Tmrt. Then, from 9:00 to 16:00, it maintains the highest Tmrt. At the end of the day, the thermal behavior of the courtyards is similar to each other. The main atmospheric parameters of these courtyards are approximately equal, but Rlw warming has a different value for each courtyard. These values represent the air temperature change due to longwave flux divergence. This value shows higher changes compared to the others $(0 \%=0.65 \mathrm{~K} / \mathrm{h}, 10 \%=0.43,15 \%=0.41,20 \%=0.44$ $\mathrm{K} / \mathrm{h}$ ), and higher air temperature variations based on long wave flux divergence will definitely cause higher Tmrt.

The results discussed in this section are represented by PET thermal index. On average, the courtyard containing $0 \%$ water in the cold climate of Ardabil has a better thermal condition than the other conditions $(0 \%=-10.8$, $10 \%=-13.1,15 \%=-13.1,20 \%=-12.4^{\circ} \mathrm{C}$ ). The hourly frequency of PET is described in Fig 12 . 


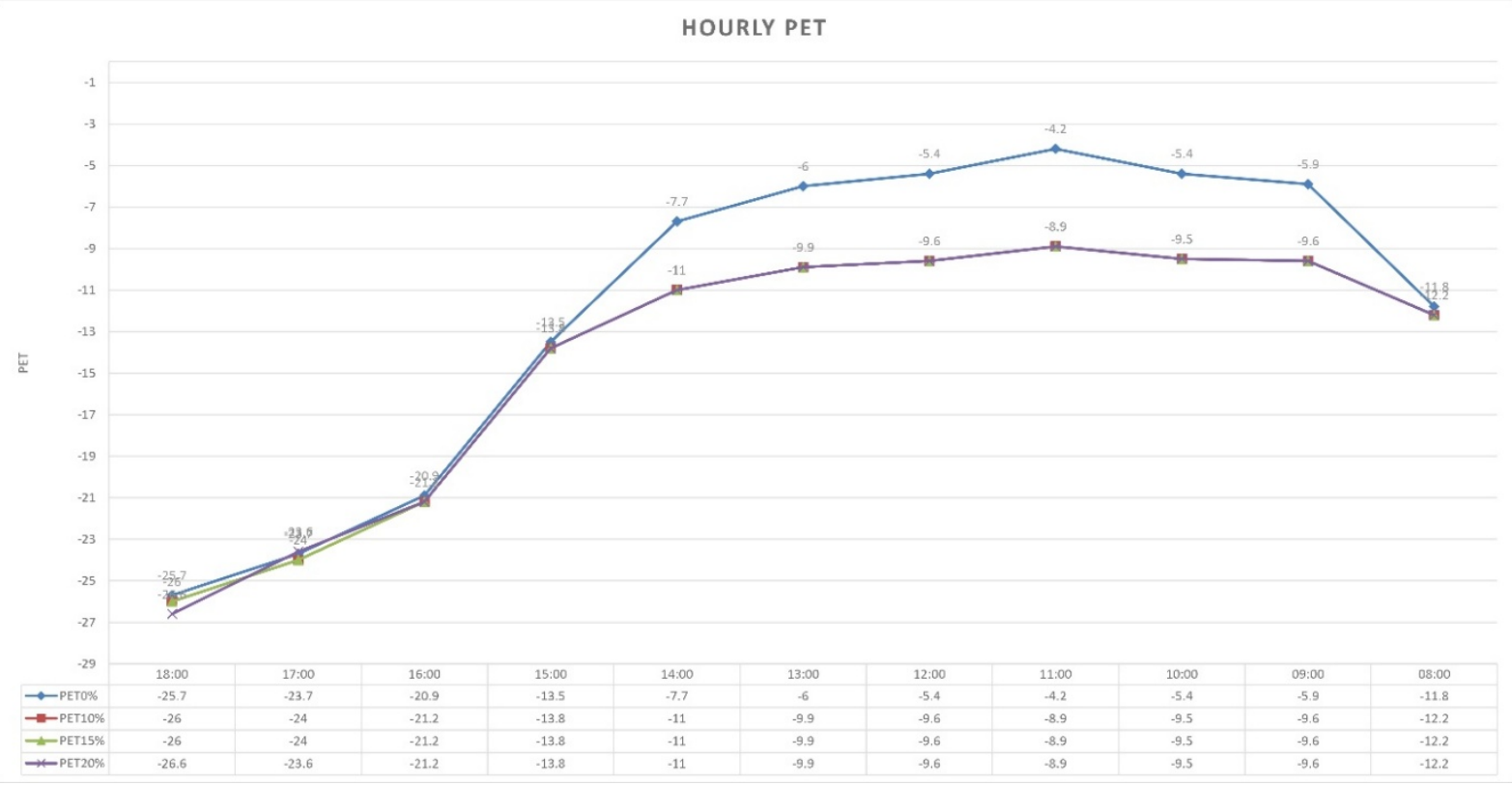

Figure 12. Hourly frequency of PET based on water.Ardabil

\subsubsection{Yazd Water Amount Analyze}

A comparison of the results of the water levels in the $10 \%$ area (as a better condition of courtyards) shows that air temperatures are different with different amounts of water $\left(0 \& 10 \%=24.36^{\circ} \mathrm{C}\right.$ and $\left.15 \& 20 \%=27.5\right)$. It also shows that the relative humidity is changed by Ta changing and water percentage. There is a $3.41 \%$ difference between the highest and lowest relative humidity of the courtyards $(0 \& 10 \%=56.05 \%, 15 \& 20 \%=$ $52.65 \%$ ). Accordingly, there are different Tmrt in these courtyards based on different levels of water percentage. On average, the courtyard that is covered $10 \%$ by water has the better thermal condition and it is $9.05^{\circ} \mathrm{C}$ cooler than the hottest courtyard $\left(0 \%=44.25^{\circ} \mathrm{C}, 10 \%=38.58^{\circ} \mathrm{C}, 15 \& 20 \%=47.53^{\circ} \mathrm{C}\right)$. The hourly frequency of the mean radiant temperatures of courtyards is described in Fig 13.

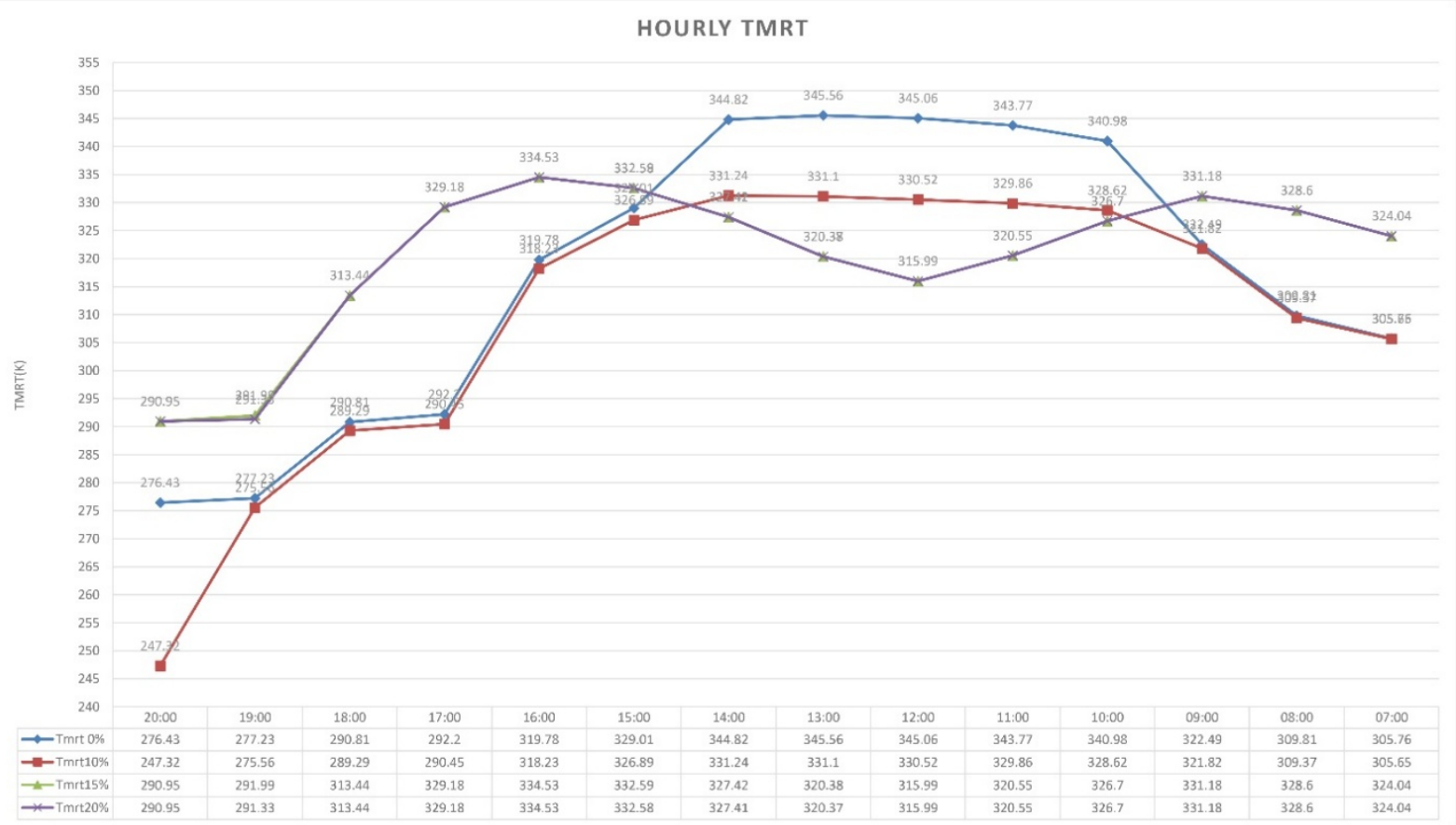

Figure 13. Hourly frequency of Tmrt of Yazd(water amount) 
Based on Fig13, with the exception of the $20 \%$ courtyard, the courtyards have equal Tmrt at the beginning of the morning. By sunrise, the thermal behavior of the courtyards is different. At 12:00, the $0 \%$ courtyard has the highest and the $15 \%$ and $20 \%$ have the lowest Tmrt. The $10 \%$ is in the middle. In the afternoon, the $20 \%$ is still in the highest condition, but the $10 \%$ reaches the lowest Tmrt and - according to what has been discussed before - on average. The $10 \%$ courtyard has a $10^{\circ} \mathrm{C}$ cooler environment in terms of Tmrt. The PET values of these conditions have been calculated and the results demonstrate that, on average, the $10 \%$ courtyard has a more comfort condition $\left(0 \%=27.6^{\circ} \mathrm{C}, 10 \%=25.4^{\circ} \mathrm{C}, 15 \& 20 \%=31.9^{\circ} \mathrm{C}\right)$. The hourly frequency is described in Fig14.

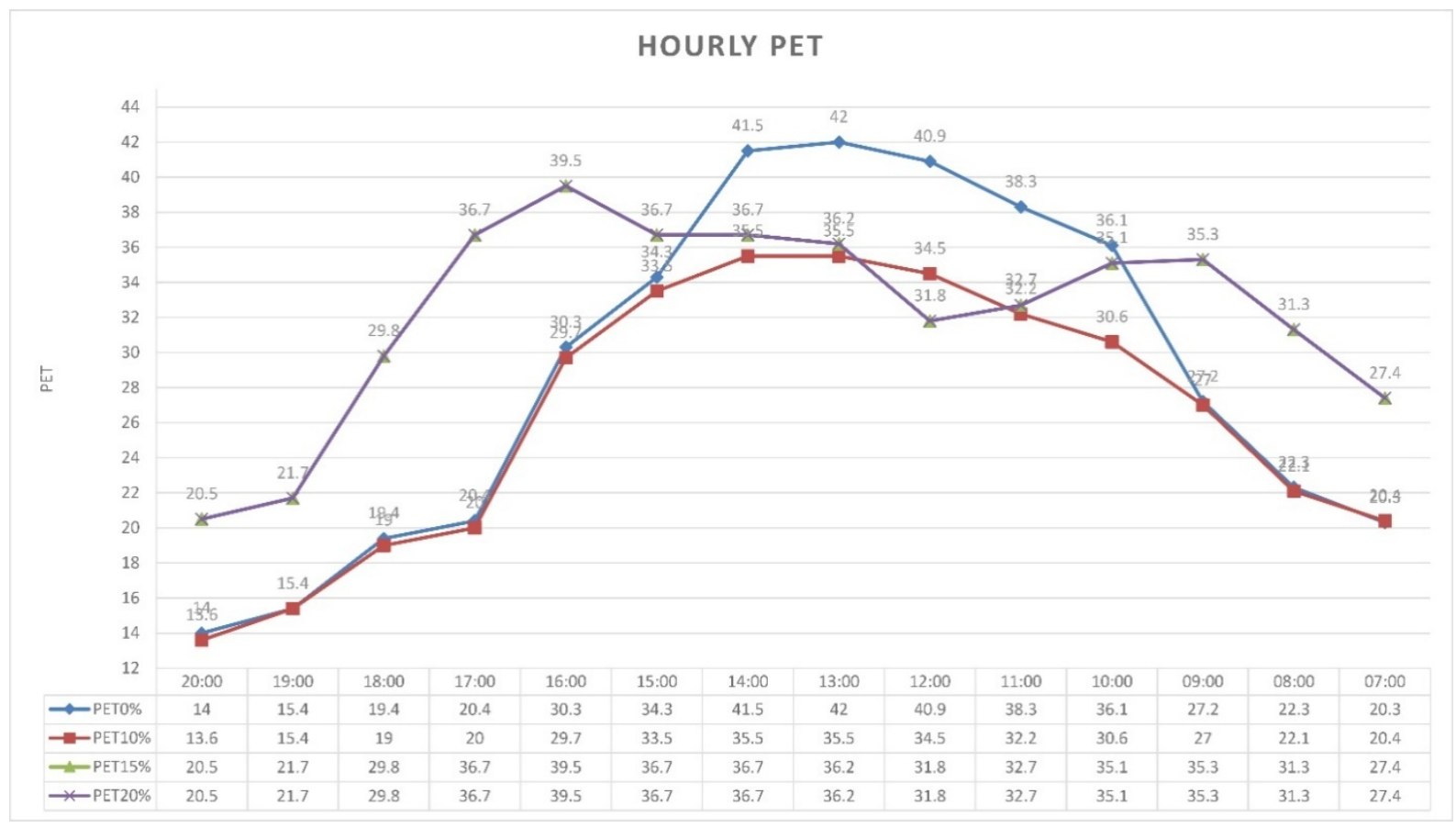

Figure 14. Hourly frequency of PET based on water amount.Yazd

\subsubsection{Effect of Vegetation}

Green spaces and utilization of vegetation in the courtyard will modify the different environmental parameters in open spaces and also in courtyards. Based on the traditional courtyards in both climates, four levels of greening were examined and stimulated with $0 \%, 20 \%, 40 \%$ and $60 \%$ of the courtyard being covered by vegetation. The use of different vegetation will affect the climatic features such as Ta, Tmrt, wind speed and humidity. These results were recorded using the values assumed by previous parameters in the center of the courtyard spaces.

\subsubsection{Microclimatic Effect of Vegetation in the Courtyard of Ardabil}

In this section, as a final step, the different levels of greening were simulated in the best area percentage of the courtyard in the very cold climate of Ardabil. A comparison of the data shows that the air temperature of different greening conditions varies by $1.6^{\circ} \mathrm{C}\left(0 \%=-11.475^{\circ} \mathrm{C}, 20 \%=-12.38^{\circ} \mathrm{C}, 40 \%=-12.87^{\circ} \mathrm{C}, 60 \%=-\right.$ $13.1^{\circ} \mathrm{C}$ ). As was the case because of frozen degrees, the relative humidities of all conditions are $100 \%$, besides the Ta, wind velocities and mean radiant temperatures are changing correspondingly by vegetation changes. On average, the wind speed of the courtyards are decreasing with the vegetation percentage $(0 \%=3.96,20 \%=3.23$, $40 \%=2.99,60 \%=2.9^{\circ} \mathrm{C}$ ), and there is $1.06 \mathrm{~m} / \mathrm{s}$ of difference between the $60 \%$ tree-covered spaces and noncovered one.

The next step is to calculate the PET thermal index. The mean radiant temperatures were used to analyze the effect of vegetation on outdoor thermal comfort. Therefore, on average the $20 \%$ covered courtyard has the highest Tmrt on the coldest day of winter $\left(0 \%=24.58,20 \%=31.49,40 \%=26.05,60 \%=24.49^{\circ} \mathrm{C}\right)$. The hourly frequency of Tmrt is described in Fig15. 


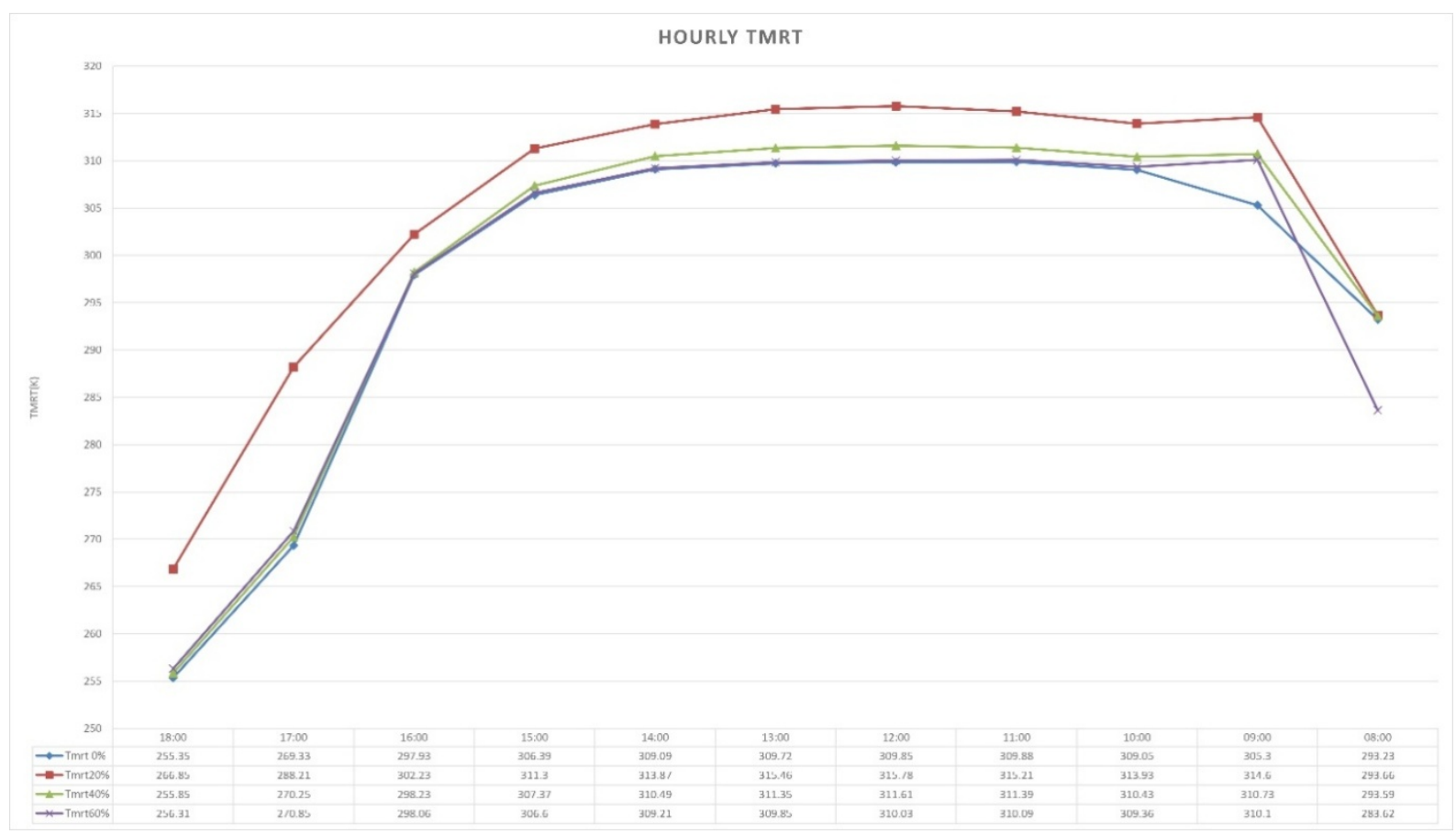

Figure 15. Hourly frequency of Tmrt based on vegetation percentage

According to the calculation formula of the Tmrt in ENVI-met model in its initial stage, (Thorsson et al., 2007):

$$
\text { Tmrt }=\left[\left(G T+273.14^{4}+\frac{1.1 * 10^{8} \mathrm{Va}^{0.6}}{\delta} *(\mathrm{Tg}-\mathrm{Ta})\right] \cdot{ }^{0.4}{ }^{1 / 4} 273.15\right.
$$

Where

Tmrt is the mean radiant temperature $(\mathrm{K})$,

GT is the globe temperature $(\mathrm{K})$,

Va is the air velocity near the globe $(\mathrm{m} / \mathrm{s})$,

$\delta_{\text {is }}$ the emissivity of the globe which normally is assumed 0.95 ,

$\mathrm{D}$ is the diameter of the globe (m) which typically is $0.15 \mathrm{~m}$, and

Ta is the air temperature $(\mathrm{K})$.

Accordingly, Tmrt is the total amount of direct and diffuse radiation on a specific point. Wind speed has an inverted effect on the Tmrt by $10^{8} * 0.6$ near to Globe. This means that an increase in wind velocity results in a decrease in radiant temperature, so Tmrt is affected by SWdir, SWdiff and also wind speed. In the $20 \%$ covered courtyard, the sum of wind speed and the radiation amount create suitable for a combination of these two. So the PET average values $\left(0 \%=-12.68,20 \%=-10.60,40 \%=-12.06,60 \%=-12.61^{\circ} \mathrm{C}\right)$ show that the $20 \%$ courtyard is $2^{\circ} \mathrm{C}$ warmer on the PET scale. The hourly frequency of PET is described in Fig 16 : 


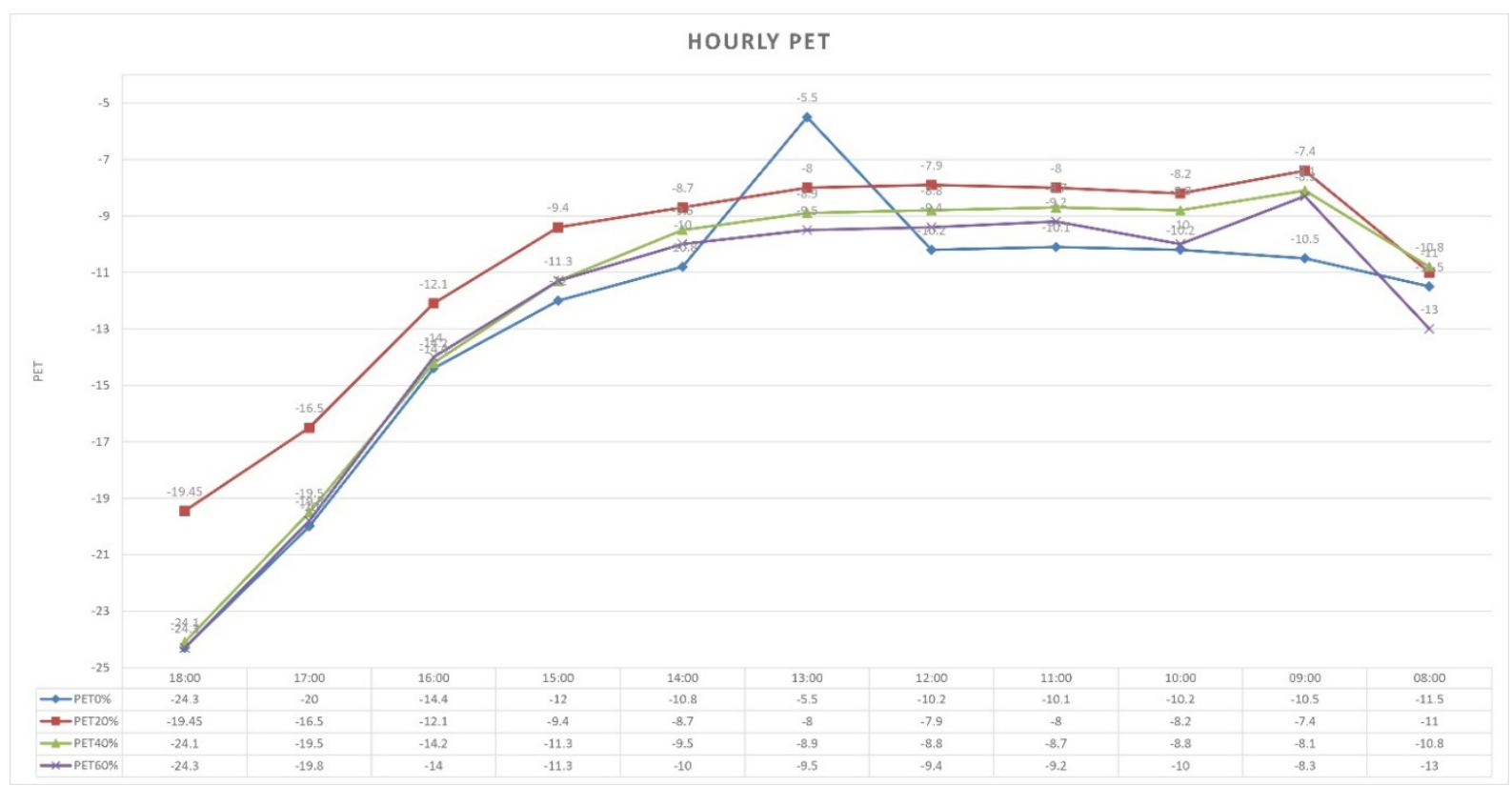

Figure 16. Hourly frequency of PET based on vegetation in Ardabil

According to Fig 16, the $20 \%$ covered courtyard achieves the highest PET value.

\subsubsection{Microclimatic Effect of Vegetation in the Courtyard of Yazd}

Based on the methods used in Ardabil courtyards, the effects of vegetation were investigated by simulation. In comparison of Ta, the results shows that there is less than $0.25^{\circ} \mathrm{C}$ between the maximum and minimum $(0 \%=$ $24.51,20 \%=27.31,40 \%=27.27,60 \%=27.24{ }^{\circ} \mathrm{C}$ ). In contrast to the conditions in Ardabil, there is different relative humidity due to the different $\mathrm{Ta}$ and vapor content of the air. On average, there is $1.28 \%$ difference between the highest and lowest relative humidity in these simulations $(0 \%=52.64,20 \%=53.33,40 \%=53.67$, $60 \%=53.92^{\circ} \mathrm{C}$ ). Wind velocities are changing in line with alterations to vegetation levels, and by increasing the vegetation percentage in these courtyards wind speeds are decreased $(0 \%=2.35,20 \%=1.92,40 \%=1.60,60 \%$ $\left.=1.43^{\circ} \mathrm{C}\right)$. On average, the $20 \%$ courtyard has the lowest Tmrt $(0 \%=59.32,20 \%=54.65,40 \%=56.45,60 \%=$ $56.32^{\circ} \mathrm{C}$ ) . Hourly frequency of Tmrt is described in Fig17. 


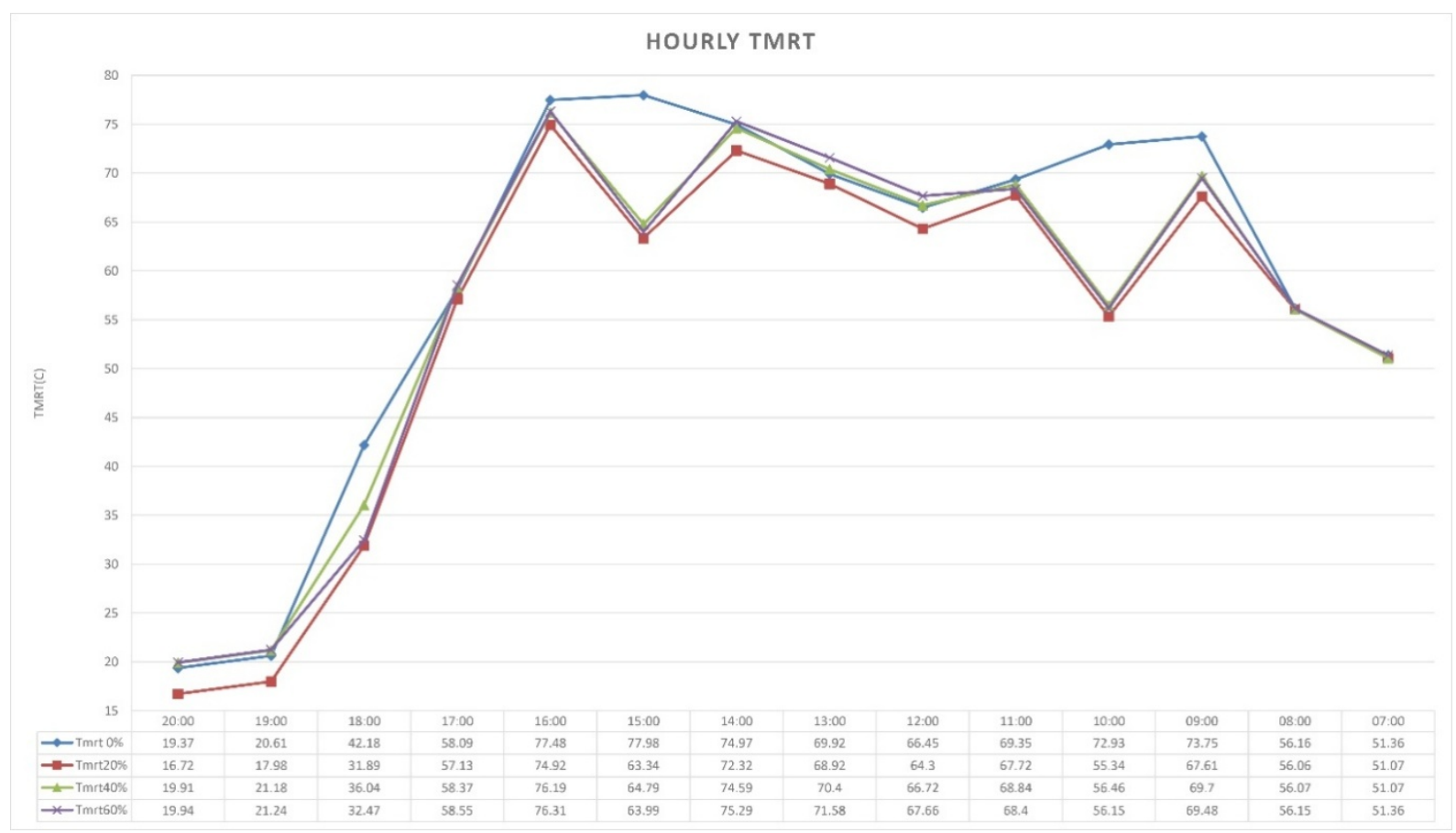

Figure 17. Hourly frequency of Tmrt based vegetation in Yazd

The Tmrt were derived and compared in order to determine the coolest courtyards in terms of vegetation different percentages. The results show the $20 \%$ covered has the lowest Tmrt among all conditions. According to what has been discussed in the previous section, and based on a formula to have a lower Tmrt, the courtyard needs less direct and diffuse radiation and also high wind speed. The optimum combination of vegetation and wind speed occurs in a $20 \%$ courtyard.

The final step is to calculate the PET thermal index by Rayman 1.2 , to find each average $(0 \%=37.3,20 \%=$ $35.37,40 \%=37.21,60 \%=37.7^{\circ} \mathrm{C}$ ).

In order to assess the comfort condition, the hourly frequency of PET value described in FIG18. 


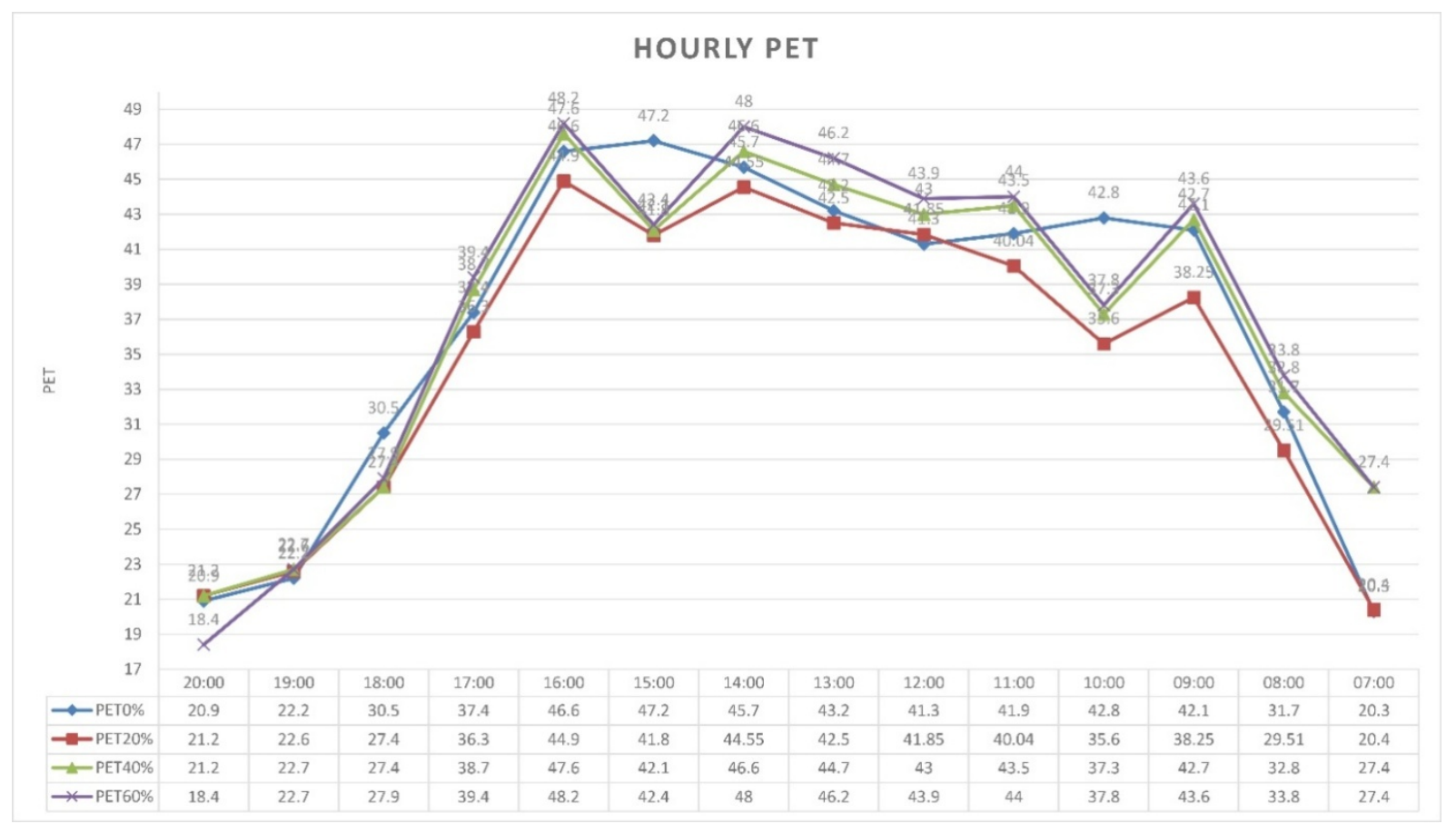

Figure 18. Hourly frequency of pet based on vegetation in Yazd

As shown in Fig12, the 20\% tree-covered courtyard has a significantly cooler PET value based on what has previously been explained. This courtyard has the best combination of wind speed and tree coverage.

\section{Conclusion}

Open spaces and their quality roughly depend on their thermal condition. Better thermal comfort condition of courtyards was proved in many types of research, and it is a common strategy in traditional architecture to modify the climatic conditions. Courtyards were mostly investigated in hot-arid and humid conditions. Uniform use of the courtyards in a different climate is a contemporary architecture issue. Therefore, a study of the physical features of traditional courtyards in a different climate in Iran could be undertaken. The results could then be compared to those found in Iranian conditions, and contextual guidelines for courtyards in fewer arid conditions could be drawn up.

Accordingly, the thermal comfort achieved during the critical day of each climate (rough clod of Ardabil, hotarid of Yazd) was selected to assess the thermal comfort condition in low contrast courtyards. Results presented new practical guidelines as to how to best adapt the contemporarily-built environment with the climate based on traditional factors to reach sustainable contextual courtyards. Reliable simulation methods present optimum solutions to create thermally comfortable courtyards in the real world. As a first step, physical features of 16 traditional courtyards of both climates were analyzed. Three main features of the courtyard were considered in analyzing:

(i) The ratio of the courtyard area to the total area of the house

(ii) The ratio of the water area to the total area of the courtyard

(iii) The ratio of the vegetation area to the total area of the courtyard

Based on the results of this section, the range of the simulation parameters was determined.

1) Initially, in order to have optimum solar radiation in both direct and diffuse conditions, the area of the courtyard was simulated. The simulation showed that the optimum courtyard size for the hot and arid climate of Yazd was $10 \%$ of the total area of the house. In contrast, to have more radiation in the rough winters of Ardabil, the optimum courtyard size is $60 \%$ of the total area of the house. Based on the PET results, there are $6.8^{\circ} \mathrm{C}$ differences between the $10 \%$ and $60 \%$ courtyards area in Ardabil, and by increasing the sky exposure condition the $60 \%$ courtyard reaches the more SW.dir and SW.diff. Therefore, high Tmrt causes high PET values. In contrast, the area percentage of the courtyards of Yazd, due to having less solar radiation in hot summer day $10 \%$ percent courtyard area were recommended with ENVI-met4 results. By this means in average the $10 \%$ courtyard 
area reaches less solar radiation and it has more shaded surfaces on a hot summer day of Yazd. Pet results demonstrate the cooler environment of Yazd accordingly at 15:00 there is a $9.8^{\circ} \mathrm{C}$ differences between the hottest and the coolest courtyard.

2) The second step was to analyze the effect of using water as the main component in a traditional courtyard. The ratio of the water area to the total area of courtyards was simulated, and the results show that every condition except the $0 \%$ (water) courtyards produced a cooler environment in very cold winter of Ardabil (as happens in traditional courtyards). There was a $16.59^{\circ} \mathrm{C}$ difference between the $0 \%$ courtyards and the others at 13:00. PET values demonstrate the warmer environment of a $0 \%$ courtyard in comparison with the others by $4.7^{\circ} \mathrm{C}$ of PET.

Water area simulation results for Yazd's hot climate demonstrate that $10 \%$ of the water area is the optimum option in the hot and arid climate of Yazd. However, at 12:00 the $20 \%$ water courtyard has the coolest environment. During the day it has a high Tmrt temperature, but the $10 \%$ water area courtyard has a low temperature rather than the other models in average condition (during the referenced day).

3) The final step in courtyard simulation. The courtyards were simulated in 4 conditions $(0 \%, 20 \%, 40 \%$, and $60 \%$ tree covered area). At the Tmrt calculation formula present, it is summed up the direct and diffuse radiation and it is affected by wind speed inversely. The optimum conditions in which to have higher Tmrt in the presence of vegetation is a $20 \%$ tree covered area. The PET values of the show that effectively the $20 \%$ courtyard has a warmer environment in the rough, cold winter day in Ardabil.

These conditions were simulated to the hot-arid climate of Yazd, and the results show that the optimum tree covering of $20 \%$ results in less radiation and enough wind speed in the Yazd hot-arid climate. The hourly frequency of the Tmrt shows that, on average, there are $4.65^{\circ} \mathrm{C}$ differences between the highest and lowest Tmrt and accordingly the results of PET values demonstrate that among the different tree coverage, the $20 \%$ tree covered courtyard has better conditions than the others and, on average, has a $2.33^{\circ} \mathrm{C}$ cooler environment than the hottest one.

\section{References}

Ahmed, K. S. (2003). Comfort in urban spaces: defining the boundaries of outdoor thermal comfort for the tropical urban environments. Energy and Buildings, 35(1), 103-110. https://doi.org/10.1016/S0378-7788(02)00085-3

Aldawoud, A. (2008). Thermal performance of courtyard buildings. Energy and Buildings, 40(5), 906-910. https://doi.org/10.1016/j.enbuild.2007.07.007

Aldawoud, A., \& Clark, R. (2008). Comparative analysis of energy performance between courtyard and atrium in buildings. Energy and Buildings, 40(3), 209-214. https://doi.org/10.1016/j.enbuild.2007.02.017

Al-Hemiddi, N. A., \& Al-Saud, K. A. M. (2001). The effect of a ventilated interior courtyard on the thermal performance of a house in a hot-arid region. Renewable Energy, 24(3), 581-595. https://doi.org/10.1016/S0960-1481(01)00045-3

Ali-Toudert, F., \& Mayer, H. (2006). Numerical study on the effects of aspect ratio and orientation of an urban street canyon on outdoor thermal comfort in hot and dry climate. Building and environment, 41(2), 94-108. https://doi.org/10.1016/j.buildenv.2005.01.013

Al-Masri, N., \& Abu-Hijleh, B. (2012). Courtyard housing in midrise buildings: An environmental assessment in hot-arid climate. Renewable and Sustainable Energy Reviews, 16(4), 1892-1898. https://doi.org/10.1016/j.rser.2012.01.008

Almhafdy, A., Ibrahim, N., Ahmad, S. S., \& Yahya, J. (2013). Courtyard Design Variants and Microclimate Performance. Procedia-Social and Behavioral Sciences, 101, 170-180. https://doi.org/10.1016/j.sbspro.2013.07.190

Andrade, H., \& Alcoforado, M.-J. (2007) Microclimatic variation of thermal comfort in a district of Lisbon (Telheiras) at night. Theoretical and Applied Climatology, 92, 225-37. https://doi.org/10.1007/s00704-007-0321-5

Attia, S. (2006). The role of landscape design in improving the microclimate in traditional courtyard buildings in hot arid climates. In Proceedings of 23rd International Conference on Passive and Low Energy Architecture-PLEA 2006 (pp. 22-24). PLEA-Université de Genève-groupeénergie.

Behbood, K. T., Taleghani, M., \& Heidari, S. (2010). Energy Efficient Architectural Design Strategies in Hot-Dry Area of Iran: Kashan. Emirates Journal for Engineering Research, 15(2), 85-91.

Berkovic, S., Yezioro, A., \& Bitan, A.(2012). Study of thermal comfort in courtyards in a hot arid climate. Sol 
Energy, 86, 1173e86. https://doi.org/10.1016/j.solener.2012.01.010

Chow, W. T., \& Brazel, A. J. (2012). Assessing xeriscaping as a sustainable heat island mitigation approach for a desert city. Building and Environment, 47, 170-181. https://doi.org/10.1016/j.buildenv.2011.07.027

Coch, H. (1998). Bioclimatism in vernacular architecture. Renewable and Sustainable Energy Reviews, 2(1), 67-87. https://doi.org/10.1016/S1364-0321(98)00012-4

Costello, V. F. (1977). Urbanization in the Middle East. CUP Archive.

Djalilian, S., \& Tahbaz, M. (2006, September). Climate control strategies used in rural housing: Ardabil Province. In PLEA 2006: Proceedings of the 23rd Conference on Passive and Low Energy Architecture (pp. 6-8).

Dunham, D. (1961). The courtyard house as a temperature regulator. Ekistics, 11(64), 181-186.

Edwards, B., Sibley, M., Hakmi, M., \& Land, P. (2006). Courtyard housing: past, present \& future. Oxon: Taylor $\&$ Francis.

Emmanuel, R., \& Johansson, E. (2006). Influence of urban morphology and sea breeze on hot humid microclimate: the case of Colombo, Sri Lanka. Climate Research, 30, 189-200. https://doi.org/10.3354/cr030189

Etzion, Y. (1990). The Thermal Behaviour of Non-Shaded Closed Courtyards in Hot-Arid Zones. Architectural Science Review, 33(3), 79-83.

Fahmy, M., \& Sharples, S. (2009). On the development of an urban passive thermal comfort system in Cairo, Egypt. Building and Environment, 44(9), 1907-1916. https://doi.org/10.1016/j.buildenv.2009.01.010

Ghaffarianhoseini, A., Berardi, U., \& Ghaffarianhoseini, A. (2015). Thermal performance characteristics of unshaded courtyards in hot and humid climates. Building and Environment, 87, 154-168. https://doi.org/10.1016/j.buildenv.2015.02.001

Gulyas, A., Unger, J., \& Matzarakis, A. (2006). Assessment of the microclimatic and human comfort conditions in a complex urban environment: modeling and measurements. Building and Environment, 41, 1713-22. https://doi.org/10.1016/j.buildenv.2005.07.001

Heidari, S. (2000). Thermal comfort in Iranian courtyard housing (Doctoral dissertation, University of Sheffield).

Heidari, S. (2010). A deep courtyard as the best building form for desert climate, an introduction to effects of air movement (Case study: Yazd). Desert (2008-0875), 15(1).

Höppe, P. (1999). The physiological equivalent temperature - a universal index for the bio meteorological assessment of the thermal environment. Int. J. Biometeoroi, 43, 71-75. https://doi.org/10.1007/s004840050118

Huttner, S., \& Bruse, M. (2009, June). Numerical modeling of the urban climate-a preview on ENVI-met 4.0. In 7th International Conference on Urban Climate ICUC-7, Yokohama, Japan (Vol. 29).

Huttner, S., Bruse, M., \& Dostal, P. (2008, October). Using ENVI-met to simulate the impact of global warming on the microclimate in central European cities. In 5th Japanese-German Meeting on Urban Climatology (pp. 307-312). Freiburg, Germangy: Meteorological Institute, Albert-Ludwigs-University.

Johansson, E. (2006). Influence of urban geometry on outdoor thermal comfort in a hot dry climate: a study in Fez, Morocco. Building and environment, 41(10), 1326-1338. https://doi.org/10.1016/j.buildenv.2005.05.022

Lin, T. P., Matzarakis, A., \& Huang, J. J. (2006).Thermal comfort and passive design of bus shelters. In: Proceedings of 23rd conference on passive and low energy architecture, Geneva; 2006.

Makaremi, N., Salleh, E., Jaafar, M. Z., \& GhaffarianHoseini, A. (2012). Thermal comfort conditions of shaded outdoor spaces in hot and humid climate of Malaysia. Building and environment, 48, 7-14. https://doi.org/10.1016/j.buildenv.2011.07.024

Manioğlu, G., \& Y1lmaz, Z. (2008). Energy efficient design strategies in the hot dry area of Turkey. Building and Environment, 43(7), 1301-1309. https://doi.org/10.1016/j.buildenv.2007.03.014

Matzarakis, A., Rutz, F., \& Mayer, H. (2007). Modelling radiation fluxes in simple and complex environments-application of the RayMan model. Int $J$ Biometeorol, 51, 323-334. https://doi.org/10.1007/s00484-006-0061-8

Matzarakis, A., Mayer, H., \& Iziomon, M. G. (1999). Applications of a universal thermal index: physiological equivalent temperature. Int. J. Biometeorol, 43, 76-84. https://doi.org/10.1007/s004840050119

Mirmoghtadaee, M. (2009). Process of housing transformation in Iran. Journal of Construction in Developing 
Countries, 14(1), 69-80.

Muhaisen, A. S. (2006). Shading simulation of the courtyard form in different climatic regions. Building and Environment, 4l(12), 1731-1741. https://doi.org/10.1016/j.buildenv.2005.07.016

Muhaisen, A. S., \& Gadi, M. B. (2006). Effect of courtyard proportions on solar heat gain and energy requirement in the temperate climate of Rome. Building and Environment, 41(3), 245-253. https://doi.org/10.1016/j.buildenv.2005.01.031

Namin, F. N., \& Khoshvalad, N. (2015). Climate Impact on the Architecture Ardabil City.

Oliveira, S., \& Andrade, H. (2007). An initial assessment of the bioclimatic comfort in an outdoor public space in Lisbon. International Journal of Biometeorology, 52, 69-84. https://doi.org/10.1007/s00484-007-0100-0

Pourvahidi, P., \& Ozdeniz, M. B. (2013). Bioclimatic analysis of Iranian climate for energy conservation in architecture. Scientific Research and Essays, 8(1), 6-16.

Prata-Shimomura, A. R., Monteiro, L. M., \& Frota, A. B. (2009). Physiological equivalent temperature index applied to wind tunnel erosion technique pictures for the assessment of pedestrian. The seventh International Conference on Urban Climate. 29 June - 3 July 2009, Yokohama, Japan.

Rajapaksha, I., Nagai, H., \& Okumiya, M. (2003). A ventilated courtyard as a passive cooling strategy in the warm humid tropics. Renew Energy, 28(11), 1755-78. https://doi.org/10.1016/S0960-1481(03)00012-0

Rajapaksha, I., Nagai, H., \& Okumiya, M. (2003). A ventilated courtyard as a passive cooling strategy in the warm humid tropics. Renewable Energy, 28(11), 1755-1778. https://doi.org/10.1016/S0960-1481(03)00012-0

Sadafi, N., Salleh, E., Haw, L. C., \& Jaafar, Z. (2011). Evaluating thermal effects of internal courtyard in a tropical terrace house by computational simulation. Energy Build, 43(4), 887-93. https://doi.org/10.1016/j.enbuild.2010.12.009

Safarzadeh, H., \& Bahadori, M. N. (2005). Passive cooling effects of courtyards. Build Environ, 40(1), 89-104. https://doi.org/10.1016/j.buildenv.2004.04.014

Saito, I., Ishihara, O., \& Katayama, T. (1990). Study of the effect of green areas on the thermal environment in an urban area. Energy and Buildings, 15(3-4), 493-498. https://doi.org/10.1016/0378-7788(90)90026-F

Shashua-Bar, L., \& Hoffman, M. E. (2004). Quantitative evaluation of passive cooling of the UCL microclimate in hot regions in summer, case study: urban streets and courtyards with trees. Building and Environment, 39(9), 1087-1099. https://doi.org/10.1016/j.buildenv.2003.11.007

Shokouhian, M., Soflaee, F., \& Nikkhah, F. (2007). Environmental effect of the courtyard in the sustainable architecture of Iran (cold regions). In 2nd PALENC Conference and 28th AIVC Conference on Building Low Energy Cooling and Advanced Ventilation Technologies in the 21st Century.

Song, Y., Li, J., Wang, J., Hao, S., Zhu, N., \& Lin, Z. (2015). Multi-criteria approach to passive space design in buildings: Impact of courtyard spaces on public buildings in cold climates. Building and Environment, 89, 295-307. https://doi.org/10.1016/j.buildenv.2015.02.025

Spagnolo, J., \& de Dear, R. J. (2003). A field study of thermal comfort in outdoor and semioutdoor environments in subtropical Sydney, Australia. Building and Environment, 38, 721-38. https://doi.org/10.1016/S0360-1323(02)00209-3

Sthapak, S., \& Bandyopadhyay, A. (2014). Courtyard houses: An overview. Recent Research in Science and Technology, 6(1).

Taban, M., Pourjafar, M. R., Bemanian, M. R., \& Heidari, S. (2014). Determining optimal courtyard pattern in Dezful traditional houses by relying on Shadow analysis.

Taleghani, M., Kleerekoper, L., Tenpierik, M., \& van den Dobbelsteen, A. (2015). Outdoor thermal comfort within five different urban forms in the Netherlands. Building and environment, 83, 65-78. https://doi.org/10.1016/j.buildenv.2014.03.014

Taleghani, M., Sailor, D. J., Tenpierik, M., \& van den Dobbelsteen, A.(2014). Thermal assessment of heat mitigation strategies: the case of Portland State University, Oregon, USA. Build Environ, 73, 138-50. https://doi.org/10.1016/j.buildenv.2013.12.006

Taleghani, M., Tenpierik, M., \& van den Dobbelsteen, A. (2012). Environmental impact of courtyards-a review and comparison of residential courtyard buildings in different climates. College Publishing, 7(2), 113-136. https://doi.org/10.3992/jgb.7.2.113 
Taleghani, M., Tenpierik, M., \& van den Dobbelsteen, A. (2014). Energy performance and thermal comfort of courtyard/atrium dwellings in the Netherlands in the light of climate change. Renewable Energy, 63, 486-497. https://doi.org/10.1016/j.renene.2013.09.028

Taleghani, M., Tenpierik, M., van den Dobbelsteen, A., \& Sailor, D. J. (2014). Heat in courtyards: A validated and calibrated parametric study of heat mitigation strategies for urban courtyards in the Netherlands. Solar Energy, 103, 108-124. https://doi.org/10.1016/j.solener.2014.01.033

Teimourtash, S. (2013). Building orientation in the traditional architecture of the hot-dry region of Iran the example of the cities Yazd and Esfahan. Bauphysik, 35(5), 356-360. https://doi.org/10.1002/bapi.201320040

Thorsson, S., Honjo, T., Lindberg, F., Eliasson, I., \& Lim, E. M. (2007). Thermal comfort and outdoor activity in Japanese urban public places. Environment and Behavior, 39, 660-84. https://doi.org/10.1177/0013916506294937

Thorsson, S., Lindberg, F., Eliasson, I., \& Holmer, B. (2007). Different methods for estimating the mean radiant temperature in an outdoor urban setting. International Journal of Climatology, 27(14), 1983-1993. https://doi.org/10.1002/joc.1537

Wong, N. H., Chen, Y., Ong, C. L., \& Sia, A. (2003). Investigation of thermal benefits of rooftop garden in the tropical environment. Building and environment, 38(2), 261-270. https://doi.org/10.1016/S0360-1323(02)00066-5

Wong, N. H., Jusuf, S. K., Syafii, N. I., Chen, Y., Hajadi, N., Sathyanarayanan, H., \& Manickavasagam, Y. V. (2011). Evaluation of the impact of the surrounding urban morphology on building energy consumption. Solar Energy, 85(1), 57-71. https://doi.org/10.1016/j.solener.2010.11.002

Yang, S. R., \& Lin, T. P. (2016). An integrated outdoor spaces design procedure to relieve heat stress in hot and humid regions. Building and Environment. https://doi.org/10.1016/j.buildenv.2016.01.001

Yao, R., \& Steemers, K. (2013). Urban microclimates and simulation. In Design and Management of Sustainable Built Environments (pp. 77-97). Springer London. https://doi.org/10.1007/978-1-4471-4781-7_5

Yaşa, E., \& Ok, V. (2014). Evaluation of the effects of courtyard building shapes on solar heat gains and energy efficiency according to different climatic regions. Energy and Buildings, 73, 192-199. https://doi.org/10.1016/j.enbuild.2013.12.042

Zhai, Z. J., \& Previtali, J. M. (2010). Ancient vernacular architecture: characteristics categorization and energy $\begin{array}{lllll}\text { performance } & \text { evaluation. } & \text { Energy and }\end{array}$ https://doi.org/10.1016/j.enbuild.2009.10.002

Zhang, X., Jin, H., \& Dong, X. (2015). Numerical Simulation Analysis on Wind Environment of Traditional Village Courtyard in Severe Cold Regions. In Renewable Energy in the Service of Mankind Vol I (pp. 405-414). Springer International Publishing. https://doi.org/10.1007/978-3-319-17777-9_36

\section{Copyrights}

Copyright for this articleis retained by the author(s), with first publication rights granted to the journal.

This is an open-access article distributed under the terms and conditions of the CreativeCommons Attribution license (http://creativecommons.org/licenses/by/4.0/). 